PONTIFÍCIA UNIVERSIDADE CATÓLICA DO RIO DE JANEIRO

A influência do marketing no futebol feminino

Ariane Azevedo Silva

Trabalho de Conclusão de Curso

Centro de ciências socials - CCS

DePARTAMENTO dE AdMINISTRAÇÃO

Graduação em Administração de Empresas 
Ariane Azevedo Silva

\section{A influência do marketing no futebol feminino}

Trabalho de Conclusão de Curso

Trabalho de Conclusão de Curso, apresentado ao programa de graduação em Administração da PUC-Rio como requisito parcial para a obtenção do título de graduação em Administração.

Orientador(a): Marco Aurélio Sá Ribeiro

Rio de Janeiro

Julho de 2021. 


\section{Agradecimentos}

Primeiramente quero agradecer os meus pais, Angelo e Luciana, por terem me dado todo apoio durante a minha vida, me ajudando a ser a mulher que sou hoje e por terem se dedicado a oferecer a melhor educação, por terem confiado em mim e pelas oportunidades proporcionadas. Também quero agradecer aos meus padrinhos, Alexandre e Cláudia, pelo apoio e torcida durante esses anos.

Quero agradecer às minhas companheiras da PUC, Aline, Catarina, Gisele, Lara e Patrícia por todos os bons momentos, apoio emocional, pelos resumos compartilhados durante os 5 anos de curso, por terem me incentivado a cada vez aprender mais e por terem sofrido comigo nas matérias mais difíceis do curso. Obrigada meninas, por todo o suporte e carinho.

A todos os meus amigos do Colégio Notre Dame Ipanema, Carlos, Fabiana, Felipe, Gabriela, João Guilherme, Maria Carolina, Renata, Patrick e Yara por todos os bons momentos e por terem aguentado os meus desabafos sobre a faculdade. Também quero agradecer aos meus amigos da vida, que conheci no Colégio Sion, Amanda, Carol, Gabriela, e Ricardo, por anos de companheirismo, risadas, momentos incríveis, e pelos puxões de orelha quando precisava. Obrigada pela confiança, por tantas alegrias, pelo carinho e pelos conselhos.

Por fim, o meu agradecimento especial vai para o meu orientador Marco Aurélio. Eu não poderia ter escolhido melhor, muito obrigada pela paciência, companheirismo e por ter me ensinado tanto dentro quanto fora da sala de aula. À PUC-Rio e ao IAG, o meu obrigada por sempre serem tão solícitos e por 5 anos incríveis. 


\title{
Resumo
}

Azevedo, Ariane. Influência do Marketing no Futebol Feminino. Rio de Janeiro, 2021. 57 p. Trabalho de Conclusão de Curso - Departamento de Administração. Pontifícia Universidade Católica do Rio de Janeiro.

O presente estudo tem como objetivo investigar a relação das ações de marketing com a visibilidade do futebol feminino para os fãs do esporte. Para que fosse possível atingir esse objetivo final, foi realizado um estudo sobre o marketing nos eventos e a influência das marcas nas gerações mais novas, de forma que os seus motivos dessa visão.

Além disso, foram realizadas entrevistas com pessoas fãs do esporte. $\mathrm{Na}$ análise desses resultados foram utilizadas as literaturas sobre marketing de serviços e de eventos, marketing esportivo e o poder das marcas nos esportes.

Palavras- chave

Marketing de serviço, Marketing de Eventos, Marketing Esportivo, Marcas no Esporte

\begin{abstract}
Azevedo, Ariane. The influence of marketing on women 's soccer. Rio de Janeiro, 2021. 57 p. Trabalho de Conclusão de Curso - Departamento de Administração. Pontifícia Universidade Católica do Rio de Janeiro.
\end{abstract}

This study aims to investigate the relationship of marketing actions with the visibility of women's soccer for fans of the sport. In order to achieve this goal, a study was carried out on marketing at events and the influence of brands on younger generations, so that their reasons for this vision.

In addition, interviews were conducted with people who are fans of the sport. In the analysis of these results, literature on service and event marketing, sports marketing and the power of brands in sports were used.

Keywords

Service Marketing, Event Marketing, Sports Marketing, Brands in Sport 


\section{Sumário}

1. O tema e o problema de estudo 1

1.1. Introdução ao tema e ao problema do estudo 1

1.2. Objetivo do Estudo 3

1.3. Objetivos intermediários do estudo 3

1.4. Delimitação e foco do estudo 5

1.5. Justificativa e relevância do estudo 6

$\begin{array}{lll}2 . & \text { Referencial teórico } & 7\end{array}$

2.1. O Marketing de Serviço e o Marketing de Eventos 7

2.1.1. Marketing de Serviço e o Modelo de 5 GAP's 8

$\begin{array}{ll}\text { 2.1.2. } & \text { Marketing de Eventos }\end{array}$

2.2. O Poder das Marcas no Esporte 15

$\begin{array}{ll}\text { 2.3. } & \text { Marketing Esportivo no Futebol } \\ \end{array}$

3. Métodos e procedimentos de coleta e de análise de dados do estudo 23

3.1. Etapas de coleta de dados 23

3.2. Fontes de informação selecionadas para coleta de dados no estudo 24

3.3. Procedimentos e instrumentos de coleta de dados utilizados no estudo 25

3.4. Formas de tratamento e análise dos dados coletados para o estudo 25

3.5. Limitações do Estudo 26

4. Apresentação e análise dos resultados 27

$\begin{array}{ll}\text { 4.1. Visão do Esporte } & 27\end{array}$

4.1.1. Posicionamento de serviços 30

4.2. O evento esportivo 32

$\begin{array}{lll}\text { 4.3. Empresas no esporte } & 37\end{array}$

5. Conclusões e recomendações para novos estudos 43

6. Referências Bibliográficas 46 


\section{Lista de figuras}

Figura 1: Brasão colorido da PUC-Rio - Exemplo de figura com legenda formatada

Lista de Tabelas

Tabela 1: Perfil dos Entrevistados. 


\section{O tema e o problema de estudo}

Esse capítulo volta-se à apresentação do tema que se pretende desenvolver e do problema de estudo.

Assim, apresenta-se o problema que suscitou a proposta de investigação e respectivos objetivos de pesquisa. Na sequência, são indicadas as suposições e as hipóteses do estudo e se informa a relevância e justificativa do estudo e a delimitação e foco do estudo.

\subsection{Introdução ao tema e ao problema do estudo}

O esporte feminino durante muito tempo foi deixado em segundo plano, já que começou a ser regularizado bem depois do esporte masculino. Acreditava-se que as mulheres não eram capazes de ter o mesmo rendimento que os homens e que alguns esportes, como o futebol, eram considerados violentos. Por isso, durante 40 anos as mulheres brasileiras não puderam praticar vários esportes que fossem contra a sua natureza. A justificativa dessa proibição era relacionada com a preservação do corpo da mulher -elas não poderiam participar de atividades físicas muito impactantes, já que poderia causar infertilidade-, de acordo com o Decreto Lei 3199 de abril de 1941, imposto durante o governo de Getúlio Vargas.

Segundo a historiadora norte-americana Mary Jo Festle apud Miriam Adelman, (2003, p.4) "[...] as mulheres atletas sempre tiveram de encarar o preconceito social de dois tipos: primeiro, que suas 'diferenças físicas' as fazia muito menos competentes para o esporte do que os homens, e, segundo, que a prática esportiva as masculiniza, tornando-as mulheres 'anormais' e/ou lésbicas".

A pesquisadora Ludmila Mourão, da Universidade Federal de Juiz de Fora (UFJF), pontuou que "são recentes as conquistas das mulheres em esportes de alto rendimento". Nos jogos olímpicos de Londres, em 2012, segundo o Comitê Olímpico Internacional, todas as nações tiveram ao menos uma atleta em suas delegações. De acordo com a pesquisadora, os Estados Unidos da América (EUA) protagonizaram um fato inédito: "pela primeira vez, o número de atletas mulheres superou o de homens", disse. Nas Olimpíadas de 2016, realizadas no Rio de Janeiro, os números foram ainda melhores: eles registraram o maior número de mulheres nos esportes, enquanto elas somaram $45 \%$ dos participantes, uma 
diferença baixa na comparação com os homens, de acordo com a matéria feita pelo Secad feita em 2018.

Apesar da grande evolução da participação das mulheres nos esportes profissionais ao longo dos anos, elas ainda sofrem muitos desafios. No futebol, a seleção feminina dos Estados Unidos, que já chegou a cinco finais de Copas do Mundo -ganhando quatro delas- recebem seis vezes menos que os jogadores da seleção masculina, que nunca chegaram a uma final de Copa do Mundo, de acordo com Samir Mello (2019).

Nos últimos 13 anos, a atacante Marta Vieira da Silva, no elenco da Seleção desde 2003, foi finalista 12 vezes do prêmio de Melhor Jogadora do Mundo da Fifa, conquistou o título cinco vezes e foi vice em outras cinco. É a maior artilheira da história das Copas do Mundo, com 17 gols, e a maior artilheira da história da Seleção Brasileira, incluindo a masculina, com 117 gols, de acordo com Amanda Kestelman (2019). E mesmo assim a jogadora ficou sem patrocínio desde julho de 2018 e afirmou que só aceitaria patrocínios quando lhe pagarem o mesmo que a um homem.

No Brasil, boa parte das marcas que investem no futebol feminino fechou antes com o masculino. Poucos são os clubes que têm achado patrocinadores exclusivos para as mulheres. De acordo com a consultoria Brand Finance, o futebol feminino tem uma subvalorização de seus patrocínios avaliada em cerca de US $\$ 1,2$ bilhão. Eles também destacam que para as mulheres reduzirem essa defasagem é necessário buscar contratos de patrocínio independentes do futebol masculino.

Estima-se que a Rede Globo gasta aproximadamente $R \$ 1,3$ bilhão com 0 Brasileirão masculino todo ano, de acordo com Rodrigo Mattos (2016). Em 2017, as marcas Banco Itaú, Brahma, Chevrolet, Johnson \& Johnson, Ricardo Eletro e Vivo desembolsaram cada um $R \$ 283$ milhões para veicular suas marcas nos estádios e durante as transmissões na TV. Mas essas mesmas marcas não fazem essas campanhas com o futebol feminino. A Caixa Econômica Federal, em 2017, era a única patrocinadora do Brasileirão feminino, desembolsando, anualmente, $\mathrm{R} \$ 10$ milhões, dinheiro insuficiente para custear todas as despesas. No campeonato feminino, em 2017, dos 140 jogos que aconteceram, somente 10 jogos foram transmitidos pelo Grupo Globo, enquanto todos os 380 jogos do masculino foram transmitidos, de acordo com Naiara Albuquerque (2017).

Entretanto, a Copa do Mundo da França, realizada em 2019, começou a chamar a atenção para esses problemas. Várias marcas, como Guaraná Antártica, 
Avon, O Boticário, DMCard, GOL e Lay's, começaram a fazer campanhas sobre a seleção e investiram no futebol feminino. A Copa do Mundo de 2019 quebrou uma série de recordes da modalidade. Ela foi a mais vista da história e superou 1 bilhão de espectadores, aumento de $30 \%$ em relação à última edição, de acordo com o Jornal O Globo (2019).

Com a falta de patrocínios e campanhas, os campeonatos femininos lutam para se manter vivos. Durante muito tempo, as pessoas acreditaram que o futebol feminino era de pior qualidade em comparação ao masculino. Todavia, com as campanhas de marketing feitas para a Copa Feminina de 2019 a visão dos jovens e adultos mudou, fazendo com que as pessoas achassem que o esporte feminino tivesse a mesma qualidade.

Além disso, outro fator que pode influenciar nas campanhas de marketing e na visibilidade do esporte é a nova onda feminista, que começou a ganhar mais força em 2015. O movimento também luta para dar visibilidade aos esportes femininos, principalmente ao futebol, dando vozes às jogadoras e reivindicando os mesmos salários e visibilidade dos homens.

Levando em consideração o que foi exposto, cabe a seguinte pergunta: como a falta de campanhas de marketing no futebol feminino pode influenciar na visibilidade do esporte?

\subsection{Objetivo do Estudo}

Considerando as ações de marketing feitas para o futebol feminino, bem como a sua visibilidade na sociedade, este trabalho tem como objetivo contribuir para investigar a relação das ações de marketing com a visibilidade do futebol feminino para os fãs do esporte.

\subsection{Objetivos intermediários do estudo}

Para se atingir o objetivo final proposto esse estudo prevê, como objetivos intermediários a serem alcançados:

- Identificar os vários alvos das ações de marketing 
Este objetivo pretende mapear o público-alvo inicial do futebol feminino, fazendo assim uma breve análise e esclarecendo as suas peculiaridades. As ações e escolhas relacionadas ao marketing do esporte são utilizadas a fim de fazer negócio com esse público, sendo assim importante identificar o seu quem será o seu público inicial para fazer o esporte crescer e ser tão reconhecido quanto o futebol masculino.

- Identificar as expectativas do consumidor quando assistem ao esporte.

Aqui pretende-se analisar o que o consumidor espera ao consumir o serviço. O que leva a assistir à partida ao que espera que o entretenimento possa Ihe proporcionar

- Identificar os valores que motivam esses consumidores a assistirem esse esporte.

O objetivo desse tópico é analisar os valores que motivam os consumidores em questão a utilizar esse serviço. Nesse caso, os valores que vão ser analisados não estão ligados aos aspectos econômicos do consumo, mas às percepções e escolhas, que são fruto da cultura e da sociedade que estão inseridos.

- Relacionar as ações de marketing antes da Copa do Mundo de futebol feminino e durante o evento com as percepções e atitudes do consumidor quanto a adesão do esporte.

A partir deste objetivo serve para se compreender os efeitos que as práticas de marketing durante a Copa do Mundo de 2019 possuem relação com a percepção do consumidor em relação ao futebol, incluindo as campanhas realizadas antes deste evento.

- Debater se o uso diferenciado das ferramentas de marketing pode ou não mudar a visibilidade do esporte feminino. 
Com as informações obtidas nos objetivos anteriores procura-se concluir quanto a importância do marketing para o futebol feminino e se ele demonstra requerer uma estratégia própria voltada a ele.

\subsection{Delimitação e foco do estudo}

Este estudo volta-se mais especificamente para abordar a questão de como são utilizadas as ferramentas de marketing para promover o esporte feminino, mais especificamente o futebol, e quais as atitudes e visão dos consumidores em relação ao futebol. Tal ângulo de análise se mostra interessante e importante porque há falta de estudos acadêmicos sobre o tema. Além disso, o movimento feminista trouxe novas possibilidades para o futebol feminino que era ofuscado pelo futebol masculino, sendo a principal delas a criação de campeonatos nacionais e consequentemente o aumento no número de campanhas de marketing.

O futebol feminino ganhou espaço no mercado esportivo contrariando os padrões historicamente impostos às mulheres. Embora esse crescimento já venha acontecendo a algum tempo e os números sobre a qualidade das jogadoras se mostrem expressivos, há falta de informações sobre esta área. Estudos sobre o marketing esportivo tem se concentrado apenas sobre os esportes masculino, incluindo o futebol, ocasionando em uma falta de informações referente ao marketing no futebol esportivo, especialmente no Brasil, onde as matérias e estudos começaram a ser realizados depois de 2019, ano da Copa do Mundo feminina

O estudo também irá analisar a percepção do futebol pelos consumidores relacionado às ferramentas utilizadas pelas empresas patrocinadoras, já que uma das consequências do uso dessas ferramentas é afetar a visibilidade do esporte, afetando o conhecimento dos campeonatos, na quantidade de público e como os consumidores pensam em relação a ela.

Não se pretende tratar, mesmo sendo relevante, uma análise financeira do futebol feminino. $O$ foco consiste na visibilidade do esporte e como as ferramentas de marketing são utilizadas para o mesmo e não se isso gera impacto financeiro para as marcas ou atletas. 


\subsection{Justificativa e relevância do estudo}

As informações que esse estudo pretende produzir podem se mostrar de interesse as empresas que querem patrocinar atletas e eventos ligados ao futebol feminino e/ou fazer campanhas ligadas ao mesmo, pois pretende descrever informações ligadas às decisões de marketing de um mercado pouco explorado $\mathrm{e}$ que não é analisado academicamente, que é o mercado de marketing esportivo no futebol feminino.

Os estudos existentes abordam o marketing esportivo, porém com o foco no futebol masculino. Apesar de que o esporte feminino tem ganhado mais força e visibilidade nos últimos anos, a dinâmica do mercado se mostra diferente devido aos estereótipos e ao atraso do desenvolvimento do futebol feminino.

Os resultados a serem alcançados também poderão ser úteis para as outras pesquisas e trabalhos do meio acadêmico, uma vez que pode vir a refletir as diferenças de visibilidade no campo esportivo. Além disso, com as informações geradas de como os consumidores reagem ao marketing feito pelas empresas no ramo esportivo, outras empresas interessadas e os campeonatos de futebol femininos poderão escolher as melhores estratégias para realizarem as suas campanhas, já que o futebol feminino tem uma dinâmica diferente da do masculino. 


\section{Referencial teórico}

Neste capítulo são apresentados e discutidos aspectos conceituais e estudos relacionados ao tema e estudo em investigação e que servirão de base para a análise realizada.

Esta seção está dividida em três partes e abordam, respectivamente, os conceitos de marketing de serviços e marketing de eventos, baseando- se em Lovelock; Wirtz e Hemzo (2012) e H.L Hoyle Jr. (2003), respectivamente, com o objetivo de analisar de que maneira os conceitos de marketing têm sido associados e aplicados aos eventos esportivos, promovendo assim um parâmetro para comparação com o futebol feminino.

Na segunda seção será abordado o poder das marcas, a fim de ilustrar como as marcas podem influenciar a visão do conhecimento dos clientes em relação ao futebol, principalmente no futebol feminino.

Por fim, na terceira seção serão discutidos os modelos e táticas do marketing esportivo, com o intuito de identificar os efeitos esperados do marketing utilizada pelo futebol feminino segundo a teoria.

\subsection{O Marketing de Serviço e o Marketing de Eventos}

De forma generalista, Kotler (2011) define o marketing como um meio pelo qual indivíduos têm suas necessidades e desejos atendidos através de criação, oferta e troca de produtos de valor com outros.

A Associação Americana de Marketing apud Sandhusen (2011) acredita que o marketing tem a finalidade de produzir e manter relacionamentos que possam satisfazer intenções individuais e organizacionais por meio do procedimento de planejar e efetivar a concepção, a promoção e a distribuição de ideia, estabelecimento de preços, bens, serviços, organizações e eventos.

Numa definição moderna, ele consiste em uma disputa pela fidelidade do consumidor (McKENNA, 1992 apud VIELA; MARQUES, 2018). Com essa evolução, Las Casas (2009) discorre que o relacionamento passou a ser considerado uma maneira de obter vantagem competitiva em um ambiente comercial.

O marketing passou por um processo de evolução ao longo dos anos, que começou na fase 1.0 e atualmente está na 3.0. A fase 1.0 teve sua presença na era industrial, onde o marketing consistia na venda de produtos a todos que se 
interessassem, objetivando atingir o mercado de massa, em bens básicos e padronizados. Já a fase 2.0 originou-se na atual era da informação, na qual há meios para os consumidores se manterem informados e poderem realizar comparações entre produtos semelhantes. É a fase orientada para o cliente, visto que o valor do produto é definido por ele e a área de marketing precisa realizar a segmentação do mercado e criar produtos para um mercado-alvo específico (KOTLER; KARTAJAYA; SETIAWAN, 2012, apud VIELA; MARQUES, 2018).

O marketing tem a possibilidade de orientar as empresas para que elas possam atender, com eficiência e eficácia, as necessidades e desejos de seus clientes (COBRA; URDAN, 2017 apud VIELA; MARQUES, 2018). Nesse sentido, deve haver reconhecimento e satisfação dos desejos do cliente, e todo o sistema de negócios deve ser direcionado a ele (ETZEL; WALKER; STANTON, 2001).

Com a utilização do marketing busca-se atingir a satisfação recíproca de consumidores e produtores por meio do desenvolvimento dinâmico e intenso de trocas entre pessoas e organizações (GIOIA, 2013). Um de seus elementos consiste na promoção de produtos e serviços para que o consumidor os conheça e se motive a comprá-los (TEIXEIRA et al., 2010).

Com o passar dos anos e na medida em que o acesso à informação se tornou mais amplo, percebeu-se que o consumidor se utiliza cada vez mais de diversas informações e fontes de dados para tomar decisões de compra, estabelecendo certa hierarquia de valores, desejos e necessidades baseado em dados empíricos, propaganda de boca-a-boca, opiniões diversas e experiências anteriores com serviços e produtos (McKENNA, 1992).

\subsubsection{Marketing de Serviço e o Modelo de 5 GAP's}

De acordo com Lovelock; Wirtz e Hemzo (2011), serviços são atividades econômicas que uma parte oferece a outra, implicando um intercâmbio de valor entre vendedor e comprador em um mercado. Em troca de dinheiro, tempo e esforço, os consumidores de serviços esperam receber o valor do acesso a bens, mão de obra, habilidades profissionais, instalações, redes e sistemas, mas eles não costumam deter a propriedade de qualquer um dos elementos físicos envolvidos.

A experiência é um ponto importante no setor de serviços. Nesse setor as pessoas podem fazer parte da experiência do serviço. Segundo Ray (2008), as experiências interrompem as pessoas das suas vidas e expectativas para fornecer algo de interesse, que exige atenção e que por si só é incrivelmente envolvente. 
O marketing experiencial pode ocorrer em qualquer indústria ou setor, que pode ir desde o de bens até ao de serviços. (Chris Voss e Leonieke Zomerdijk, 2007).

De acordo com Lovelock; Wirtz e Hemzo (2011), os clientes precisam ser educados sobre a melhor forma de usar um serviço, pois se o cliente souber usar bem um serviço além de ter uma melhor experiência e resultado ele também terá uma maior eficiência que poderá impulsionar a produtividade da empresa e reduzir os custos. Se o cliente não aprender alguns procedimentos específicos e entender a sua importância, o serviço principal pode ter seu risco de fracasso aumentado significativamente.

Outro ponto que os autores chamam a atenção é para a interação entre os clientes, que pode afetar a experiência do serviço. A forma como os clientes se veste, quem são e como se comportam servem para reforçar ou enfraquecer a imagem que uma empresa tenta projetar e a experiência que ela quer criar.

Nos últimos anos, a indústria do futebol sofreu grandes inovações, uma vez que os seus modelos de negócio foram evoluindo. No entanto, o core business continua a ser o mesmo: o jogo. Desta forma, os clubes têm alargado o leque de serviços para que possam equilibrar as suas contas.

De acordo com Lindon (2004) e Mason (1999), o desporto tem um conjunto de especificidades muito particulares. A inexistência de concorrência, por exemplo, seria uma oportunidade num outro negócio, mas neste caso poderia ser uma ameaça ao mercado desportivo. Não deixando de estar relacionadas, a incerteza do resultado e a espontaneidade da atuação dos "artistas" levam os consumidores a seguirem ou não com maior regularidade os espetáculos desportivos. Importa perceber que o produto essencial (o jogo) não depende dos responsáveis de marketing (Lindon, 2004), não invalidando, contudo, estes profissionais de continuarem à procura de diversificação do portfólio de serviços e produtos em redor dos seus clubes, de forma a levar ao incremento das receitas para o produto mais relevante: o plantel principal. Hoje, o produto principal do futebol está rodeado por um conjunto de serviços e merchandising que são usados para proporcionar uma mais consistente experiência desportiva (Smith \& Stewart, 2010).

Encontros corporativos, convenções religiosas, comemorações cívicas, reuniões, eventos esportivos, angariação de fundos entre outros eventos são beneficiados pelos princípios de marketing de eventos introduzidos pelos pioneiros da arte, e aperfeiçoados por legiões de praticantes. (Hoyler Jr., 2013) 
O surgimento e a consolidação do mercado consumidor de espetáculo são resultado de um processo de popularização, sendo assim pode se dizer que a popularização do jogo trouxe uma oportunidade para o surgimento do espetáculo no esporte (GIULIANOTTI,2002). Desta maneira, não é um evento histórico, mas uma consequência e reação de um longo processo. Mas o espetáculo pode estar relacionado a diferentes conceitos. Pallottine (2009) em Futebol, poesia e drama faz uma relação do futebol com o espetáculo emocional e teatral. A autora vê cada detalhe do jogo como parte de uma peça. Hug (2013) também vê o futebol como foto, poesia, prosa e música: uma arte completa. Mas para outros atores a ideia de espetáculo pode estar ligada ao conceito de circo, "cômico" (SOARES; LOVISOLO,2003) ou de instrumento de alienação da sociedade (LOURENÇO, 2011; LOVISOLO,2001).

De acordo com Corrêa e Caon (2008), a percepção da qualidade de um serviço é uma função da comparação que o cliente fará entre suas expectativas e sua percepção do serviço prestado, ou seja, caso o serviço prestado supere as expectativas do cliente, a qualidade do serviço será tida como alta. Em contrapartida, caso o serviço prestado não atenda às suas expectativas, esse serviço receberá uma avaliação negativa. $O$ modelo dos 5 GAPs busca equilibrar a expectativa e a percepção do serviço prestado, pela identificação e correção das lacunas nas diferentes etapas do processo de prestação de serviços, desde sua concepção até o momento em que o serviço é entregue ao cliente, levando-se também em conta os fatores que influenciam na formação da expectativa do cliente.

GAP 1: ocorre quando existem divergências entre o que o cliente espera do serviço prestado e as percepções da gerência na identificação dessas expectativas. Esse GAP é geralmente causado quando não há entendimento por parte da gerência das reais expectativas dos clientes. Ele pode ocorrer devido aos seguintes fatores: má seleção do público-alvo; falta de pesquisas de mercado para conhecimento atualizado das expectativas dos clientes; ausência de avaliação de critérios que para os clientes possam ser mais relevantes nas diferentes etapas do processo; ou até mesmo a falta de comunicação da gerência com os funcionários que possuem contato direto com os clientes.

GAP 2: ocorre quando o projeto de processo de prestação do serviço elaborado não atende às expectativas dos clientes. Para que o projeto atenda a todas as expectativas dos clientes, ele deve ser fruto de uma análise constante dos serviços prestados, de forma a eliminar as possíveis causas de falhas. 
GAP 3: ocorre quando há divergências entre a especificação do projeto de serviço e a forma como o serviço é efetivamente realizado. Imperfeições na prestação do serviço por parte dos prestadores faz com que esse GAP venha a ocorrer, podendo gerar a insatisfação dos clientes, mesmo quando se há ótimas especificações do serviço. Treinamentos e adequação ao trabalho podem evitar esse GAP.

GAP 4: ocorre quando existem divergências entre o serviço oferecido e o que é comunicado aos clientes. Esse GAP geralmente surge quando as prestadoras trazem grandes expectativas aos clientes e não conseguem atendêlas. Uma das causas desse GAP é a supervalorização ou a não valorização adequada do serviço oferecido.

GAP 5: este GAP é uma junção de todos os outros comentados acima, onde ocorre uma contraposição entre o que o cliente espera e a percepção que ele tem do serviço oferecido. É importante observar que, em alguns casos, este GAP pode esconder a existência de outros GAPs, uma vez que um determinado GAP pode ajustar os prejuízos causados por outros.

Assim, se o serviço percebido não atender às expectativas do serviço esperado, os clientes ficarão decepcionados. Empresas bem-sucedidas adicionam a suas ofertas benefícios que não somente satisfazem os clientes como também os surpreendem e encantam. Encantar clientes é uma questão de superar as expectativas (KOTLER, 2011).

De acordo com Kotler (2011), existem razões para a ocorrência desses 5 Gap's. Eles são:

Gap 1: má investigação das necessidades do cliente e comunicação deficiente com o cliente e dentro da empresa.

Gap 2: falta de compromisso com a qualidade; falta de metodologia no estabelecimento de especificações e dificuldade em perceber se é possível a execução do serviço.

Gap 3: falta de conhecimento para realizar o serviço; falta de trabalho em times e problemas de relacionamento e de motivação.

Gap 4: desconhecimento quanto ao andamento dos trabalhos; falta de controle das operações; comunicações inadequadas e motivação para exagerar a realidade.

Gap 5: é o resultado final proporcionado pelos 4 gaps anteriores. 
Com base nesse modelo, os pesquisadores identificaram cinco fatores determinantes da qualidade dos serviços que serão descritos a seguir por ordem de importância.

1. Confiabilidade - habilidade de prestar o serviço de modo confiável e exatamente como prometido.

2. Capacidade de resposta - disposição de ajudar clientes e fornecer pronto serviço.

3. Segurança - conhecimento e cortesia de funcionários e sua habilidade de transmitir confiança e segurança.

4. Empatia - atenção individualizada dispensada aos clientes.

5. Itens tangíveis - aparência de instalações físicas, equipamentos, funcionários e material de comunicação.

\subsubsection{Marketing de Eventos}

O marketing para o entretenimento não significa descobrir formas criativas de vender ingressos. Para a arte e entretenimento, o marketing tem como objetivo criar uma experiência que proporcione momentos inesquecíveis para seu cliente (HOYLE JR., 2003).

O marketing de eventos foi transformado de uma improvisação organizacional em uma disciplina profissional da qual a associação depende para sua sobrevivência. E a comunidade de associações- que são incubadoras para eventos de todos os tipos-, mais do que qualquer outra entidade, tem orientado outros tipos de planejadores de eventos para formas inovadoras e criativas de atrair a participação e seu maior subproduto- a conscientização pública. (HOYLE JR.,2003 p.32).

Os meios de comunicação de massa possuem importante papel na formação da identidade nacional, já que eles são os principais veículos para as manifestações esportivas e culturais- eles definem de certa forma a representação do sentimento de brasilidade- e o reforçam em toda nação devido ao seu grande poder de alcance. São eles que são aliados do futebol, em sua divulgação, já que o esporte também é considerado um dos principais formadores de identidade nacional, de acordo com o antropólogo Roberto DaMatta. (Prochnik, Luisa, 2011)

Um ponto importante para o sucesso do evento são as relações públicas. Uma campanha de relações públicas eficaz impactará o que outras pessoas dizem sobre a organização ou cliente. A credibilidade ou a falta dela será definida pela eficácia da atenção contínua para as relações públicas como instrumento de 
construção da imagem de sua organização a longo prazo. (HOYLER JR.,2003, p. 49).

Javalgi (1994) afirma que patrocínio é a subscrição/assinatura de um evento especial, para apoiar objetivos da empresa; através do aumento da imagem corporativa, do aumento do conhecimento de sua marca ou diretamente estimulando vendas de produtos e serviços. Entretanto, para D'Astous (1995) patrocínio é um elemento do mix de comunicação onde a empresa provém algum suporte financeiro a uma entidade, podendo ser individual (um esportista), uma organização (uma entidade social) ou um grupo (uma orquestra), permitindo esta entidade desenvolver suas atividades (evento cultural) e, ao mesmo tempo, obter benefício desta associação em termos de imagem global e conhecimento pelo consumidor do que a empresa pode oferecer.

Bennett (1999) afirma que patrocínio é uma importante ferramenta de comunicação de marketing, que busca conseguir publicidade favorável para a empresa e/ou suas marcas dentro de um público-alvo determinado, através do apoio a uma atividade não diretamente ligada ao negócio normal da empresa. Importante também a definição de Cornwell e Maignan (1998), patrocínio pode ser definido como uma troca entre patrocinadores e um evento ou atividade, onde a última recebe um fee e a primeira obtém direitos de se associar com o evento e divulgar esta associação.

Gwiner (1997) afirma que o tipo de evento pode ser categorizado em no mínimo 5 áreas: esporte, música, festivais, artes (balé, exposições, teatro) e reuniões profissionais. Existe também uma divisão entre eventos existentes (previstos no calendário) e eventos criados pelos patrocinadores. Os eventos existentes são os que já pertencem ao calendário normal de eventos realizados em um período. Por exemplo, de 4 em 4 anos ocorre uma Copa do Mundo de Futebol.

Obviamente o evento que já existe possui características conhecidas que têm uma história relacionada ao evento. D‘Astous (1995) afirma que uma vantagem associada ao patrocínio de eventos existentes é que o patrocinador pode avaliar antecipadamente o valor desse investimento. Embora haja uma lógica no pensamento do autor, nem sempre estão claras e disponíveis as informações relativas ao evento que possibilitem esta avaliação.

Algumas entidades internacionais são as principais instituições promotoras do desenvolvimento do futebol feminino mundial e, apesar da grande diferença entre as ligas e países ao redor do mundo, é visível o crescente desenvolvimento 
do futebol feminino e o aumento de mulheres praticantes da modalidade desportiva. Contudo, não se pode esquecer que há uma grande disparidade entre o senso de profissionalismo e a falta de vislumbre de um futuro, o que faz com que muitas mulheres abandonem a sonhada carreira de jogadora de futebol. (Kellermann,2020).

Um ponto positivo no desenvolvimento do futebol feminino é o latente crescimento académico que tal tema vem gerando, refletindo assim no leve aumento do interesse social e econômico, como afirma CHAPLIN (2013, p. 20) "O futebol feminino na Europa fez um enorme progresso, especialmente nos últimos 15 anos. Isto não é apenas estimado a partir do crescente número de membros das associações, mas também do crescente interesse social e econômico". E ainda conclui: Na Europa, por exemplo, já existia nesse momento um movimento concreto e positivo, onde as competições de futebol feminino se realizavam com assiduidade. A União das Associações (UEFA) estudou o assunto e chegou a estabelecer normas e disciplina sobre competições.

Segundo Jacobs (2014) (apud Kellermann, 2020), a FIFA, entre os anos de 2012 e 2015, planejou gastar uma quantia de $\mathbf{\$ \$ ~ 4 4 , 2}$ milhões para potencializar o futebol feminino em todo o mundo direcionando suas associações que investissem em governança, treinamento e o desenvolvimento do futebol juvenil - além da modalidade feminina.

Entretanto, o esporte feminino nunca teve um esquema de promoção ou de relações públicas que ajudasse o esporte a crescer. A revista Placar de agosto de 1995 aborda a eliminação da Seleção Brasileira Feminina na Copa do Mundo do mesmo ano como resultado da falta de organização e evidencia o amadorismo da modalidade, como mostra o título da matéria: "Esquema amador: quando o assunto é desorganização, as meninas não devem nada aos homens" (PLACAR, 1995, p.34 apud SALVINI \& MARCHI JÚNIOR,2013).

A realidade é complexa e revela um cenário com disparidades e dificuldades. Para as marcas investirem em uma modalidade, elas se baseiam em três premissas: preço, prazo e audiência. Ainda que o campeonato feminino possa garantir essa tríade, os anunciantes não vêm dessa forma (ALBUQUERQUE, 2017). As empresas mostram pouco interesse em investir na modalidade, com isso o futebol feminino apresenta um recurso mínimo quando comparado ao futebol masculino. O que cria um círculo desfavorável, o público não participa porque não tem a mídia, a mídia não investe porque não tem patrocinador e o patrocinador não investe porque não tem o público e a mídia. 


\subsection{O Poder das Marcas no Esporte}

De acordo com Aaker (1998), a marca é um nome ou símbolo com o objetivo de sinalizar, diferenciar e identificar organizações diante dos seus concorrentes. Marca é algo intangível, uma aura de significados que cerca o produto, empresa e/ou serviço (NEUMEIER,2008). A marca sedutora conquista, conecta e passa confiança ao público (COSTA,2007; NEUMEIER,2008). Sendo assim a marca forte vale mais que o produto, pois além de influenciar, facilitar e ajudar as decisões do consumidor, é ela que conquista a lealdade e não o produto (AAKER,1998; SAMPAIO,2003).

É através da marca que o mercado consumidor identifica os produtos de uma empresa e atribuem-Ihes valores. Confiabilidade, qualidade e status são elementos que uma marca é capaz de transmitir e são por essas razões que Kotler (2000) afirma que a marca vem adotando crescente importância como principal ativo empresarial, já sendo possível legitimá-la com um foco essencial nas ações de comunicação de marketing.

Com o objetivo de passar essas mensagens para o maior número de pessoas possível, diversas marcas vêm adotando o esporte para conseguir moldar ou modificar a sua imagem na sociedade. Em alguns o casos as marcas possuem o esporte fortemente inserido dentro de suas imagens, como no caso das marcas de artigos esportivos, que devido a características de seus produtos, participação no esporte e percepção da marca perante os consumidores, são comumente denominadas como marcas esportivas.

Segundo Kotler (2000), a força de uma marca, incluindo as marcas esportivas, é construída de maneira holística, por meio de orquestrações de um conjunto de ferramentas, inclusive propaganda, relações públicas, patrocínios, eventos, causas sociais e porta-vozes. Para as marcas esportivas o patrocínio apresenta importância singular nesse processo.

De acordo com Sampaio (2003), estamos em um período de grandes mudanças no mercado: produtos se tornam cada vez mais similares; o consumidor vem ficando mais consciente; e a importância dos canais de distribuição está em crescimento. Em um mundo onde os produtos se multiplicam e já não são o diferencial da empresa, a marca virou um elemento essencial para as instituições (NEUMEIER, 2008; SAMPAIO, 2003). Walvis (2010) argumenta que a marca pode 
ter um extraordinário valor e significado para os consumidores e, consequentemente, para as empresas que as constroem.

Atualmente, o futebol é o esporte mais popular do planeta sendo praticado por homens e mulheres, adultos e crianças, não importando a nacionalidade ou classe social (STOLEN et al., 2005). O interesse pelo futebol é tanto que, segundo a Kantar Sport, um terço da população mundial, 2,2 bilhões de pessoas, viram por pelo menos 20 minutos consecutivos o último Mundial de seleções realizado na África do Sul em 2010 (PORTAL 2014, 2011). E os números na internet são ainda mais impressionantes. De acordo com a Akamai, agência de monitoramento da internet, esta edição da Copa obteve um aumento de até $200 \%$ na procura pelos portais jornalísticos na rede. Seu evento inaugural que ocorreu no dia 11 de junho de 2010, com um pico de 12 milhões de visitantes simultâneos, bateu o recorde de 8,5 milhões que antes pertencia ao presidente norteamericano, Barack Obama, em sua vitória nas eleições presidenciais (CONVERGÊNCIA DIGITAL, 2010).

No Brasil essa realidade não é diferente. De acordo com Lopes (2011), o futebol ocupou em 2010 65,8\% do espaço esportivo nas mídias televisivas abertas e fechadas, deixando o segundo colocado, o tênis, muito atrás com apenas $6,5 \%$. Outro fato que comprova a força que o esporte tem no país com relação à mídia, foi a "guerra" ocorrida em 2011, envolvendo duas emissoras de televisão pela exclusividade das transmissões do Campeonato Brasileiro da série $A$ no triênio 2012-2014. A concorrência vencida pela Rede TV por um valor de $\mathrm{R} \$ 1,548$ bilhão pelas três temporadas não foi aceita pelos clubes que preferiram fechar individualmente com a Rede Globo que já vem transmitindo com exclusividade os principais campeonatos no Brasil e jogos da seleção brasileira há alguns anos (Agência Estado, 2011). Com essa negociação individual, só no ano de 2012, a arrecadação dos clubes da primeira divisão do futebol brasileiro chegou a $R \$$ 1,115 bilhão (GONÇALVES, 2013). Com toda essa procura e valorização do futebol pela mídia, as empresas cada vez mais buscam de alguma forma associar sua marca ao esporte, seja pela promoção de um evento como a Copa do Mundo ou Campeonato Brasileiro ou por patrocínios de clubes.

O desporto tem, segundo Rasquilha (2009), vantagem sobre as artes para a maioria dos patrocinadores na medida em que é, efetivamente, o primeiro campo alvo de ações de sponsorship, quer pela atenção que lhe é mundialmente dedicada quer pela consequente quantidade de empresas que pelo mesmo se interessam (Magistrali e Szybowicz, 1990). O patrocínio desportivo trata então, de acordo com Tribou (2011), de uma técnica de comunicação global que visa 
persuadir os espectadores a participarem num qualquer evento desportivo e que traduz a ligação entre o evento e a comunicação da empresa, de modo a criar bastante brand e product awareness e a obter equidade em termos de imagem, sendo que o seu objetivo consiste na transferência de alguns, ou até todos os atributos da imagem desportiva, para a empresa, pelo menos, para alguns dos seus produtos e marcas, de modo a torná-las mais eficazes no mercado (Quester, 1997).

De fato, no que ao patrocínio de carácter desportivo se refere, podemos salientar que as mais proeminentes marcas patrocinam atualmente os mais relevantes clubes desportivos (Ngan et al, 2011), formando uma aliança estratégica cujos resultados são benéficos para ambas as partes intervenientes na relação (patrocinador e patrocinado) (Mitre e Pablos, 2009), até mesmo porque, de acordo com Gwinner e Eaton (1999), os consumidores podem, de facto, associar um evento desportivo e respectivo significado à marca patrocinadora. $A$ identificação de um consumidor com uma equipa ou com um desportista é então, entendida por Gwinner e Swanson (2003), como sendo a ligação percebida pelo consumidor ou espectador em relação à sua equipa ou desportista, referindo-se também ao facto dos consumidores 23 Escola Superior de Comunicação Social experimentarem como sendo suas, as vitórias e derrotas dos mesmos.

Quanto ao patrocínio específico de futebol profissional, de acordo com Chadwick e Thwaites (2005), este continua não apenas a ser muito popular, como um dos mais populares entre as organizações. Segundo Martensen e Hansen (2004), uma audiência de um evento desportivo raramente participa no mesmo, pelo facto do nome do patrocinador estar na camisola dos jogadores ou nos telões do estádio, mas sim, pelo jogo em si. Se, por algum acaso, repararem nas mensagens do patrocinador, é provável que tal suceda com poucos níveis de atenção, baixo envolvimento e de forma muito periférica.

Cientes da grande popularidade e divulgação do futebol no Brasil, muitas empresas sentiram-se atraídas a investir em patrocínios, equipes e atletas, com o objetivo de aumentar a exposição do seu nome, marca e produto. A partir da década de 70, o esporte tornou-se uma forma eficiente de comunicação entre as organizações e seus clientes, fazendo de uma atividade de lazer um grande negócio que passou a movimentar bilhões de dólares anuais (GUARAGNA, 2005).

No futebol, os clubes negociavam espaços publicitários em seus estádios e uniformes. Algumas organizações comercializavam os direitos de imagem da credibilidade de atletas de maior prestígio e reconhecimento mundial, como o 
Pelé, para atingir objetivos organizacionais e de marketing, seja no aumento das vendas ou na percepção de valor da marca, por exemplo. As emissoras de televisão adquiriam os direitos de transmissão das partidas junto aos clubes e revendiam direitos de espaços na programação para anunciantes e patrocinadoras (GUARAGNA,2005).

Nas últimas décadas, o futebol continuou sendo utilizado como veículo de promoção, comunicação e divulgação de marcas. A promoção do esporte como produto, evento ou atividade física ou outra forma entre marketing e esporte, é desenvolvida eficientemente em muitos clubes estrangeiros com o objetivo de diversificar e aumentar suas receitas (GUARAGNA,2005).

Para Ferrand e Pages (1999), a imagem de uma organização esportiva pode agregar valor para si próprio. A imagem contribui para o reforço da marca (Brand Equity) e favorece mudanças no comportamento do consumidor. Normalmente a imagem de uma organização esportiva deriva da conotação dada ao esporte em questão, personalidades existentes em seu meio e os títulos conquistados pela entidade. Entretanto, considerando a ecletismo de organizações esportivas existentes, deve-se considerar que em grande parte elas funcionam como fenômenos sociais que projetam sua imagem. Logo pode-se considerar que as organizações promotoras de eventos esportivos são exatamente assim e o que se deseja é a projeção de sua imagem para fixação de sua marca. (Rocco de Oliveira; Mazzei; Rocco Junior; Soares César, 2013)

Infelizmente não foram encontrados como o poder das marcas pode influenciar no futebol feminino.

\subsection{Marketing Esportivo no Futebol}

O termo Marketing Esportivo surgiu no final dos anos 70, pela Advertising Age (membro filiada da Associação Americana de Marketing), para representar a utilização de técnicas de marketing dentro do esporte. Desde então os estudos cresceram, acompanhado pelo mercado e o volume de movimentação financeira gerada pelo esporte em todo mundo, a ponto de se tornar uma área específica de pesquisa.

O marketing esportivo trata dos elementos e estratégias do marketing, especificamente no contexto esportivo, para assim atender as necessidades dos clientes do esporte, mesmo que sejam consumidores individuais, participantes de esportes ou jogadores e investidores corporativos (MORGAN; SUMMERS, 2008). 
Nesse sentido, Campomar (1992) aponta que o marketing esportivo se difere do marketing convencional, uma vez que se relaciona com um ambiente de características próprias. Segundo o autor, a relação entre o marketing e o esporte manifesta-se de duas maneiras diferentes: esporte no marketing de uma organização e marketing do esporte. Segundo Bertoldo (2000), o marketing esportivo é o conjunto de ações voltadas à prática e à divulgação de modalidades esportivas, clubes e associações, seja pela promoção de eventos e torneios ou através do patrocínio de equipes e clubes esportivos.

Ainda de acordo com Campomar (1992), o marketing esportivo se desvia dos esforços convencionais de marketing, pois ele está relacionado a um campo com características próprias. Além disso, o autor defende que a relação entre o marketing e o esporte aparece de duas formas diferentes, denominadas de esporte no marketing de uma organização e de marketing do esporte.

Segundo Afif (2000), o marketing esportivo é uma das estratégias, dentro de um planejamento, que utilizam o esporte para atingir suas metas. É o processo de elaborar e programar atividades de produção, formação de preço, promoção e distribuição de um produto esportivo para satisfazer as necessidades ou desejos de consumidores através do processo de troca, e, realizar os objetivos da empresa.

De acordo com Poit (2006), o marketing esportivo trabalha com objetivos cruciais para qualquer investimento neste ramo que são fortalecimento de imagem e marca, retorno de mídia, conquista e manutenção de mercado, é usado também como ferramenta de comunicação que agrega 19 valores à marca ou a imagem, aumenta o reconhecimento do público e proporciona maior credibilidade.

O campo de atuação e abrangência do marketing esportivo é vasto e vai desde projetos de eventos até projetos de venda de patrocínio, licenciamento e de marketing para clubes, federações, ligas e confederações esportivas.

No futebol, o patrocínio esportivo apresenta-se principalmente através da publicidade e propaganda nos uniformes dos clubes, nas dependências esportivas, e no fornecimento de equipamentos esportivos a jogadores individuais de renome. Os clubes de futebol são excelentes veículos de comunicação, pois são mais baratos que a mídia televisiva e geram mais tempo de imagem do que se iguais valores fossem pagos diretamente para as emissoras na forma de comerciais.

Especificamente sobre o Futebol, Avancini (2010) divide-o em três mercados: o Produtor, o Consumidor e Intermediário. O mercado produtor é 
constituído por clubes e federações, vistos como empresas de serviços. O mercado intermediário é segmentado entre o de revenda, formado pelas empresas licenciadas e TVs que transmitem as partidas, e o industrial, que são as empresas de marketing esportivo. Por fim, o mercado consumidor é definido pelo torcedor, que tem relação diretamente com o mercado produtor, assim como com o mercado intermediário.

De acordo com Theodorakis, Wann e Weaver (2012), a identificação e comprometimento com o time e o impacto desse assunto nas atitudes e comportamentos de consumo do torcedor constituem um dos temas mais abordados nas pesquisas relacionadas ao esporte.

Proni (1998) afirma que a relação entre o esporte de forma geral e a televisão é mais complexa do que parece, isso se deve principalmente ao fato de o esporte não ser apenas um espetáculo televisivo, ou seja, não se reduz a uma mercadoria produzida para preencher a programação da televisão.

Com a chegada do século XXI e com os clubes cada vez mais necessitados de capital, as maiores e mais globalizadas equipes foram gerando uma terceira renda: o marketing. Tratava-se dos valores repassados por patrocinadores, pelo merchandising e das turnês (SORIANO,2010).

Proni (1998) credita o desenvolvimento do marketing esportivo como fator fundamental para transformar o esporte em atividade organizada empresarialmente. Essa organização foi capaz de atrair mais investidores e financiadores para um esporte como o futebol.

Diante do exposto, o futebol passou a vender não somente entretenimento, mas sim um entretenimento global. A partir dos jogos de futebol, e de alguns personagens (jogadores e treinadores), realizam-se espetáculos em massa que podem ser assistidos ao vivo.

Na visão de Silva (2011), a importância do marketing esportivo no Brasil vem crescendo, acompanhando as receitas e os ganhos do esporte. Nesse contexto, a gestão do esporte também se torna cada vez mais fundamental, e os times passam a ser mais organizados e estruturados, trazendo maiores resultados para os clubes.

Williams (2011) afirma que o futebol feminino profissional é difícil de vender e deve ser tratado como qualquer ideia de negócio, pois gera despesas consideráveis. Nesse sentido, há uma grande diferença entre o futebol masculino e feminino como capital social, uma vez que o futebol feminino é menos prestigioso como atividade e menos valioso como mercadoria. 
Devido ao grande espaço ocupado pelo futebol de homens nas mídias tradicionais, as jogadoras e alguns organizadores de equipes encontram nas redes sociais um ambiente gratuito, prático e rápido para expor seus posicionamentos.

No Brasil, marketing esportivo merece atenção quando o futebol como esporte está sendo discutido. Enquanto é o esporte mais popular do país, certos clubes tradicionais do centenário enfrentam problemas estruturais e problemas organizacionais, como má gestão práticas (Bortoluzzo, Bortoluzzo, Machado, Melhado, Trindade e Pereira, 2017; Madalozzo \& Villar, 2009). Os dois maiores clubes do país, somente o Flamengo e o Corinthians têm 32,5 e 27,3 milhões de apoiadores, respectivamente (IBOPE Inteligência, 2014). O número total de fãs desses dois clubes juntos é maior do que as populações do sul da Coréia, Espanha ou Colômbia.

De acordo com Scharf (2010) o patrocínio vem ganhando destaque entre as ferramentas de marketing esportivo, especialmente no futebol. É definida como uma troca entre patrocinador e patrocinado (NEO, 2013; MATTAR; CAMPOMAR,2011) onde um oferece dinheiro e outro oferece uma alternativa de comunicação em tom menos comercial, mais natural e sutil (CONTURSI, 2003, apud THOMAZI 2012, p.3). De acordo com Mattar e Campomar (2011). existem distintas modalidades de patrocínio, mas a esportiva é a atividade que mais recebe investimentos, sendo escolhida pelas empresas com o objetivo de potencializar e divulgar a marca junto à mídia. Podendo ser de clubes, equipes, eventos esportivos, competição, arenas e/ou atletas, ela é uma forma de desenvolver o negócio, mas também uma estratégia de comunicação, uma ferramenta de Branding, uma técnica de segmentação, posicionamento, vendas e relacionamento, sendo assim multi-funcional para uma empresa (NETO, 2013).

Hoje, vislumbra-se o desporto como uma ferramenta de modificação e fortalecimento onde as mulheres começam a ganhar espaço na sociedade mesmo com o inferior número de desportistas que participam de torneios oficiais (Ventura \& Hirot, 2007 apud Kellermann, 2020). Importa frisar que esse espaço que vem sendo conquistado a pequenos passos, teve início por mulheres "visionárias" que nos primórdios da história do futebol decidiram levantar a bandeira da igualdade e reivindicaram direitos (Costa, 2016).

TEIXEIRA e CAMINHA (2013, p. 266) acreditam que este tema está realmente em voga, quando percebemos que o futebol feminino, no âmbito desportivo mundial, vem ganhando espaço inclusive no setor acadêmico, o que 
"pode ser comprovado pela quantidade de trabalhos científicos que têm sido publicados no sentido de conferir cientificidade ao seu treinamento, prever e tratar lesões características, ou melhorar o desempenho de atletas consideradas de elite" entre diversas outras temáticas que só elevam a modalidade. 


\section{Métodos e procedimentos de coleta e de análise de dados do estudo}

Este capítulo pretende informar sobre decisões de como este estudo foi realizado.

Está dividido em cinco seções. A primeira informa sobre as etapas de coleta de dados do estudo realizado, enquanto a segunda seção comunica sobre as fontes de informação selecionadas para coleta de informações neste estudo. Logo, informa-se sobre os processos e instrumentos de coleta de dados realizados em cada etapa, com as respectivas justificativas, e na quarta seção se apresentam as formas escolhidas para tratar e analisar os dados coletados. Finalmente, a autora irá expor sobre as limitações do estudo.

\subsection{Etapas de coleta de dados}

O método de coleta de dados utilizado pela autora foi o de entrevista qualitativa, na qual a representatividade não é o fator mais importante e sim, o aprofundamento das informações transmitidas pelo grupo entrevistado (GERHARDT E SILVEIRA, 2009). Este tipo de pesquisa também pode ser utilizado para analisar atitudes, motivações e sentimentos dos entrevistados (MCDANIEL, 2003 apud VIANA, 2014).

Dessa forma, foi elaborado um roteiro de entrevista (Anexo 1) para ser utilizado com pessoas jovens que se assistem futebol masculino e que desejam acompanhar o futebol feminino. Após a realização de cinco entrevistas, os dados coletados foram processados, analisados e relacionados com algumas teorias apresentadas acima.

A pesquisa qualitativa foi escolhida, de modo que os dados coletados apresentassem uma maior qualidade e profundidade de informações a serem obtidas. Ao se utilizar esse tipo de pesquisa, é possível compreender quais são os principais aspectos motivacionais dos entrevistados e relacioná-los com a suas percepções de treinamento e desenvolvimento. 


\subsection{Fontes de informação selecionadas para coleta de dados no estudo}

Para esta etapa, a amostra selecionada de entrevistados foi de cinco pessoas, entre eles torcedores homens e mulheres entre 22 e 24 anos. A pesquisa contou com a participação de brasileiros que, atualmente, moram no Rio de Janeiro. A escolha por um grupo mais diversificado se deu pelo fato dessa faixa etária está mais disposta a assistir futebol feminino, por serem pessoas com acesso à internet e acompanharem futebol masculino. .

O número de entrevistados foi definido como cinco, pois acreditou-se que após esse número de entrevistas as respostas já teriam um grande volume de informação e as respostas poderiam se tornar repetitivas. Sendo assim, todos os entrevistados são fãs e torcedores de diferentes clubes de futebol.

\section{Tabela 1: Perfil dos entrevistados}

\begin{tabular}{|c|c|c|c|c|c|c|}
\hline \multicolumn{7}{|c|}{ Perfil dos Entrevistados } \\
\hline NOME & IDADE & FAIXA DE RENDA & TRABALHA & ESTUDA & FACULDADE & CURSO \\
\hline Entrevistado 1 & 22 anos & $\begin{array}{c}\text { Entre } R \$ 2.862,00 \text { e } R \$ \\
5.724,00\end{array}$ & Sim & Sim & UFF & Turismo \\
\hline Entrevistado 2 & 23 anos & $\begin{array}{c}\text { Entre } R \$ 5.724,00 \text { e } R \$ \\
9.540,00\end{array}$ & Sim & Sim & UFRGS & Design Gráfico \\
\hline Entrevistado 3 & 24 anos & $\begin{array}{c}\text { Entre } R \$ 5.724,00 \text { e } R \$ \\
9.540,00\end{array}$ & Sim & Não & PUC-Rio & Administração \\
\hline Entrevistado 4 & 24 anos & $\begin{array}{c}\text { Entre } R \$ 5.724,00 \text { e } R \$ \\
9.540,00\end{array}$ & Sim & Não & PUC-Rio & Administração \\
\hline Entrevistado 5 & 24 anos & $\begin{array}{c}\text { Entre } R \$ 9.540,00 \text { e } R \$ \\
14.310,00\end{array}$ & Não & Não & PUC-Rio & Administração \\
\hline
\end{tabular}

Fonte: Elaborado pela autora

De uma maneira geral, não houve nenhuma forma específica de seleção dos entrevistados. A única restrição era de que fosse um grupo bem diversificado em todos os aspectos, inclusive a faixa de renda, e que os jovens, ainda estudantes, fossem de diversas faculdades.

A ideia de utilizar um grupo reduzido é de que fossem coletados o máximo de informações possíveis, a respeito de suas motivações e suas percepções sobre o futebol feminino. 


\subsection{Procedimentos e instrumentos de coleta de dados utilizados no estudo}

Seguindo os critérios de classificação da pesquisa, foi realizada uma pesquisa qualitativa, a fim de que fosse possível melhor compreender e depois analisar os dados fornecidos pelos entrevistados. Com essa abordagem, os aspectos motivacionais e a percepção dos jovens em relação ao marketing no futebol feminino e como isso afeta a visão deles sobre o esporte conseguiram ser bem estudados pela autora.

Foi elaborado um roteiro de entrevista, composto por perguntas bem estruturadas, para serem utilizadas pela entrevistadora durante o processo. Todas as perguntas elaboradas no roteiro são referentes aos temas tratados neste estudo, ou seja, marketing esportivo, poder das marcas no esporte, marketing de serviço e marketing de eventos.

Devido à pandemia do COVID-19, as entrevistas não puderam ser realizadas presencialmente. Por esse motivo, de acordo com os horários mais convenientes para os entrevistados, a entrevistadora se reunia individualmente pela plataforma online Zoom, para que o tema do presente estudo e as perguntas fossem debatidas.

Cada entrevista teve duração média de trinta a quarenta minutos, de forma que os entrevistados não se alongassem muito e acabassem se perdendo. A entrevistadora também procurou esclarecer, para o entrevistado, todos os conceitos sobre o tema. Além disso, o registro das conversas foi feito por meio de vídeo e gravador de voz. Por fim, os dados obtidos foram registrados e consolidados em ferramentas do pacote Office, como Word e Excel.

\subsection{Formas de tratamento e análise dos dados coletados para o estudo}

Como a modalidade de pesquisa escolhida foi a pesquisa qualitativa, todos os dados obtidos nas conversas com os entrevistados foram tratados de forma não estatística. As informações coletadas das entrevistas e salvas nas gravações foram transcritas e consolidadas em um arquivo Excel.

A partir dessa compilação, os relatos dos entrevistados foram comparados e organizados de acordo com as concordâncias ou não sobre os pontos abordados na entrevista. Com isso, foi possível realizar uma análise mais 
sistemática e detalhada. No próximo capítulo, os dados serão apresentados de forma mais precisa e de acordo com os assuntos desenvolvidos no presente estudo.

\subsection{Limitações do Estudo}

Algumas limitações deste estudo foram percebidas durante a etapa de aplicação das entrevistas. A dificuldade encontrada foi em relação ao agendamento da entrevista e depois o comparecimento do entrevistado. O primeiro problema aconteceu com quase $100 \%$ da amostra de entrevistados. Uma das justificativas para essa limitação é de que apesar de todos estarem 24 cumprindo a quarentena, por orientações das autoridades de saúde, devido a pandemia do COVID, houve dificuldade em organizar as agendas de trabalho, vida pessoal e, por algumas vezes, vida acadêmica.

A segunda dificuldade não foi muito recorrente, porém ocorreu mais de uma vez. Após toda a organização de horários, na hora marcada da entrevista o entrevistado não comparecia, mesmo a entrevistadora tendo confirmado mais cedo no dia. A justificativa para esse problema vinha depois de algumas horas, com o entrevistado informando que havia esquecido de avisar mais cedo ou na hora da entrevista que teve um contratempo urgente.

Outra limitação encontrada foi em relação ao desenvolvimento da entrevista. Apesar de seguir o roteiro estruturado, por vezes, os entrevistados acabavam desviando do assunto e o tempo das entrevistas aumentava. $O$ fato não foi considerado um problema de grande impacto na coleta dos dados, pois a entrevistadora entendia a importância do entrevistado se sentir à vontade e, com delicadeza, acabava retomando para o assunto.

Apesar de existir um distanciamento da autora e a intenção de imparcialidade, no que se refere à interpretação e análise dos dados das entrevistas, é necessário admitir que alguns erros podem ocorrer no processo de registro das entrevistas e no viés da entrevistadora, ao interpretar as respostas. 


\section{Apresentação e análise dos resultados}

\subsection{Visão do Esporte}

Neste tópico, o conhecimento dos entrevistados sobre futebol feminino, todos jovens, serão relacionados com as teorias de marketing de serviço e de eventos, apresentadas no tópico 2.1 e 2.3, localizada no início do tópico sobre marketing de serviços e marketing de eventos. Para uma melhor compreensão da análise, as citações dos entrevistados serão relacionadas com Marketing de Serviços e o Modelo de 5 GAP's e Marketing Esportivo no Futebol.

De acordo com Lovelock; Wirtz e Hemzo (2011), os clientes precisam ser educados sobre a melhor forma de usar um serviço, pois se o cliente souber usar bem um serviço além de ter uma melhor experiência e resultado ele também terá uma maior eficiência que poderá impulsionar a produtividade da empresa e reduzir os custos. Sendo assim, foi possível perceber que mesmo os jovens que possuem uma grande afinidade com a internet e redes sociais eles possuem uma grande dificuldade de encontrar informações sobre o futebol feminino. Entretanto, as pessoas que seguem as páginas de seus times masculinos conseguem entender um pouco mais sobre o esporte.

Os serviços são geralmente difíceis de visualizar e compreender devido a sua intangibilidade (LOVELOCK; WIRTZ E HEMZO, 2011). Uma vez que os consumidores não podem provar, cheirar, tocar nem ouvir esses elementos, para eles pode ser mais difícil avaliar antecipadamente as importantes características dos serviços e a qualidade da execução em si. (LOVELOCK; WIRTZ E HEMZO, 2011). Mesmo o futebol masculino já sendo um esporte muito popular, os entrevistados não conheciam quase nada sobre o feminino.

Dessa forma, um papel importante das comunicações de uma empresa de serviços consiste em estabelecer confiança em suas competências pela ênfase de sua reputação e das suas credenciais e pela experiência de seus funcionários. Abaixo estão algumas das falas sobre essa comunicação das empresas:

"Acompanho algumas notícias através das redes sociais do Flamengo. Acredito que preciso ser um dos agentes de mudança do esporte, então utilizo as redes sociais do meu clube masculino para achar mais informações sobre o futebol feminino" (E3). 
"Acredito que mesmo com todas as dificuldades atualmente estou conseguindo me informar melhor sobre o futebol feminino através das redes sociais do Fluminense e, assim, ver onde os jogos estão passando" (E1).

"Acompanho muito pouco sobre futebol feminino, acredito que ele é pouco divulgado e assim não entendo muito sobre o esporte, diferente do futebol masculino, onde independentemente se alguém gosta ou não acaba escutando alguma notícia"

Independentemente da natureza do evento, o sucesso depende largamente da promoção. Ele é vital para criar conscientização do evento, desejo por participação e sentimento por parte do participante potencial de que o investimento em tempo e dinheiro vale os benefícios oferecidos (HOYLE JR.,2003 p.49). Além disso, um dos maiores desafios de marketing é manter a audiência até o final do evento. Logo, premiações estimulantes, sorteios, competições e tours pós-eventos são usados com frequência para isso (HOYLE JR.,2003 p.52).

O marketing esportivo pouco difere do marketing tradicional, devendo este apenas estar relacionado à disciplina do esporte e vinculado com premissas básicas como produto, demanda, desejo, necessidades, valor, satisfação, qualidade e mercado (CARDIA, 2004). Bertoldo (2000), enfatiza o papel do marketing esportivo em divulgar as modalidades esportivas, clubes e associações, através da promoção de eventos e torneios ou patrocínio de equipes e clubes esportivos.

De acordo com Poit (2006), o marketing esportivo trabalha com objetivos cruciais para qualquer investimento neste ramo que são fortalecimento de imagem e marca, retorno de mídia, conquista e manutenção de mercado, é usado também como ferramenta de comunicação que agrega 19 valores à marca ou a imagem, aumenta o reconhecimento do público e proporciona maior credibilidade. Entretanto, como veremos nos trechos abaixo, as empresas não tem divulgado o futebol feminino da forma mais eficiente:

"Mesmo acompanhando muito o futebol masculino, não consigo acompanhar da mesma forma o futebol feminino. O pouco que sei é sobre a Marta e algumas poucas notícias que vejo no perfil do Instagram do Flamengo. Sinto falta dessa divulgação em massa, que nem acontece com o futebol masculino." (E3).

"Conheço muito pouco sobre futebol feminino, uma vez que cresci com a cultura da 'exclusividade' do futebol masculino. Acredito que devido à falta de patrocínio, o 
futebol feminino acaba tendo mais dificuldade para se desenvolver e por consequência, não é divulgado pelas grandes empresas de comunicação" (E5).

"Atualmente, até conheço um pouco mais sobre futebol feminino graças ao Instagram do Fluminense. Porém, até 3 anos atrás só conhecia as jogadoras Marta e Formiga. A Copa do Mundo Feminina de 2019 me ajudou a ter mais curiosidade sobre o esporte. Mesmo assim ainda é muito difícil eu conseguir acompanhar, pois raramente sei quando são os jogos e onde eles vão ser transmitidos, e quando descubro, vejo a notícia depois do final do jogo" (E1).

As empresas utilizam as comunicações de marketing para persuadir o público-alvo de que seu serviço oferece a melhor solução para atender às necessidades dos clientes, em comparação com as ofertas dos concorrentes (LOVELOCK; WIRTZ e HEMZO, 2012). Mesmo que os clientes entendam o que um serviço deve prover, podem ter dificuldade para distinguir entre ofertas de diferentes fornecedores. Além de educar, a empresa precisa se diferenciar (LOVELOCK; WIRTZ e HEMZO, 2012).

Além disso, é importante para uma empresa prestadora de serviços identificar e selecionar o(s) melhor(es) segmento(s) alvo(s) para um evento ou serviço, uma vez que alguns segmentos de mercado oferecem melhores oportunidades de vendas e lucros do que outros. Esses grupos devem ser selecionados não só pelo potencial de venda, mas também com referência à capacidade da empresa de igualar ou superar ofertas dirigidas ao mesmo segmento. (LOVELOCK; WIRTZ e HEMZO, 2012).

Considerando o acima exposto, quando questionados sobre a visão que tinham sobre o futebol feminino, os entrevistados faziam muitas comparações com o futebol masculino e percebem que ainda há uma grande diferença entre os esportes. Além disso, pode-se observar que mesmo a grande maioria estando dispostos a assistir o esporte e tem mais acesso a essas informações, muitos deles ainda não conseguem chegar a essas notícias.

"Vejo que o futebol feminino tem um grande potencial, mas é pouco divulgado e por causa disso tem pouco patrocínio e por consequência é pouco divulgado. Sinto que faltam ações para divulgar os times, campeonatos, jogadoras e torneios. Entretanto, a mobilização tem crescido mesmo com a diferença de peso entre o futebol masculino e feminino. Ainda percebo que tem poucos jogos femininos em canais abertos, dificultando as pessoas verem os jogos. Observei que é a mesma coisa que acontece com o vôlei feminino, mesmo sendo um esporte que já é bem consolidado no Brasil” (E4). 
"Acredito que atualmente o futebol feminino alcançou uma visibilidade que não tinha antes, porém ainda está longe do suficiente. Ele ainda é um esporte tomado pelo machismo e tem uma grande discrepância entre o futebol masculino e feminino. A Marta

ainda é a grande estrela da seleção, porém é menos reconhecida do que outros jogadores masculinos "inforiores". Esse machismo influencia na visibilidade do esporte. Estamos longe de alcançar uma igualdade entre a modalidade feminina e masculina, já que ainda é visto como pior do que o masculino" (E1).

"Mesmo não acompanhando muito, sei que é uma modalidade que passa por muitas dificuldades, em comparação ao masculino. A falta de patrocínio, visibilidade, machismo e constante comparação com o futebol masculino são fatores que atrapalham o desenvolvimento do futebol feminino. Acredito que seja uma área difícil de trabalhar e se sustentar justamente pela falta de visibilidade e escassez de apoio" (E2).

Assim, em conformidade com o acima exposto, foi constatado que, de acordo com a teoria, as empresas e times não estão escolhendo as melhores estratégias de marketing para escolher o seu público-alvo e para se comunicar com eles, uma vez que a atração e retenção de novos clientes ainda está muito lenta, dificultando o desenvolvimento do esporte.

Será apresentado no próximo tópico, o posicionamento de serviços em mercados competitivos, referente ao fato da distinção de atributos importantes e determinantes para a escolha dos consumidores e o posicionamento de serviços. Isso contribui na imagem que os consumidores tem sobre o esporte feminino.

\subsubsection{Posicionamento de serviços}

Em um setor com poucas barreiras de entrada e muita competição, tornase mais importante para as organizações diferenciar seus produtos ou serviços de maneira significativa aos consumidores. A estratégia de posicionamento preocupa-se em criar, comunicar e manter diferenciais que serão notados e valorizados pelos consumidores com que a empresa gostaria de manter um relacionamento de longo prazo e que foram selecionados como público-alvo (LOVELOCK; WIRTZ e HEMZO, 2012).

Seguindo esse raciocínio, foi questionado por que eles acompanham ou deixam de acompanhar o futebol feminino. A maior parte deles explicou que mesmo tendo um interesse em acompanhar, não sabe por onde começar, não 
sabe onde se passa os jogos, quando vai ter algum jogo ou qual campeonato está passando:

"Como disse anteriormente, acompanho muito o futebol masculino desde criança e tenho facilidade de receber informações sobre ele. Porém, infelizmente isso não acontece com o futebol feminino, pois as poucas notícias que vejo é através do perfil do instagram do Fluminense. Normalmente quando descubro o horário de algum jogo, eles são nas horas que estou no trabalho ou na faculdade. Além disso, na maioria das vezes só descubro que aconteceu algum jogo depois que a partida está finalizada. Sinto falta dessa divulgação em massa, que nem acontece com o futebol masculino" (E3).

"Não costumo acompanhar muito nenhum esporte, mesmo assim percebo que quase não vejo notícias sobre o futebol feminino. Só sei quando tem algum jogo na época da Copa do Mundo Feminina ou quando tem algum jogo da seleção. Mesmo a minha família tendo um grande interesse em futebol, raramente escuto eles comentando sobre algum jogo ou campeonato" (E2)

"Eu sou uma pessoa que adora esportes, principalmente futebol e ginástica artística. Porém, acompanho muito pouco o futebol feminino, muito menos do que eu desejo. Isso porque não sei onde se passam os jogos, seus horários e quais torneios estão acontecendo. Sempre acompanho a Copa do Mundo Feminina e os demais jogos que passam no Sportv, uma vez que esses jogos são mais divulgados e fáceis de serem assistidos" (E1)

O posicionamento desempenha um papel fundamental na estratégia de marketing, porque associa a análise de mercado e a competitiva à análise corporativa interna. Ela possui três principais usos. O primeiro é fornecer uma ferramenta de diagnóstico útil para definir e entender as relações entre produtos e mercados. A segunda utilidade é identificar oportunidades de mercados para introduzir novos, redesenhar ou reposicionar produtos existentes e eliminar produtos que não satisfaçam às necessidades do consumidor e/ou que enfrentam concorrência excessiva, sem diferenciais competitivos. Por fim, ela é usada para tomar outras decisões de mix de marketing para se antecipar ou reagir às manobras de concorrentes (LOVELOCK; WIRTZ e HEMZO, 2012).

Dessa forma, é possível concluir que, de acordo com as falas acima mencionadas, a estratégia de posicionamento de serviços mesmo sendo um ponto muito importante para o sucesso de qualquer evento, não está sendo utilizada de forma correta, uma vez que os possíveis clientes não conseguem acompanhar os 
principais torneios. Sendo assim, no que se refere a literatura, podemos concluir que em relação às teorias utilizadas dessa ferramenta como método de atração podem ser confirmadas.

\subsection{O evento esportivo}

De acordo com Hoyle Jr (2003), a chave para ter sucesso no marketing do entretenimento é a necessidade de fornecer um tipo de entretenimento que forçará sua audiência a sair de casa para experimentar algo que não encontrará em outro lugar, porque o que está se oferecendo é diferente, exclusivo e preparado apenas para ela. A emoção é a chave para a venda de um evento memorável.

Durante as entrevistas, duas perguntas realizadas com os entrevistados foram referentes à participação deles em jogos de futebol feminino, ou seja, à sua presença em eventos relacionados ao esporte. Os entrevistados consideram que precisam participar mais ativamente do futebol feminino, e em grande maioria não precisaria de muitas campanhas de marketing para convencê-los a assistir aos jogos, seja pela TV ou nos estádios. Muitos consideram essa ação uma forma de valorizar o futebol feminino. As falas abaixo ilustram esses relatos:

"Assistira os jogos por espontânea vontade, se eles fossem mais divulgados. Acredito que o incentivo no futebol feminino deve partir das próprias mulheres, uma vez que essa diferença que nós vemos no futebol é um reflexo do que a gente vivencia no nosso dia a dia. Além disso, adoraria que os locais das partidas também fossem divulgados, para que assim eu também pudesse dar uma força para elas, da mesma forma que já faço com a equipe masculina" (E1).

"Eu já acompanho algumas notícias por conta própria, mas se ele recebesse um incentivo maior iria acompanhar mais jogos. Se eles fossem mais divulgados, seria mais fácil me programar para assistir os jogos que desejo. Para ir ao estádio já seria mais difícil, pois já não tenho esse hábito, mas iria se fosse em algum jogo importante ou se os ingressos fossem mais acessíveis" (E3).

"Mesmo gostando muito de futebol, nas condições atuais, só assistiria um jogo de futebol feminio se fosse algum jogo importante como uma final de campeonato ou a Copa do Mundo. Porém, se o esporte começar a receber mais visibilidade e investimento eu iria acompanhar da mesma forma que acompanho o time masculino. Por incrível que pareça, é mais fácil me convencer de ir ao estádio ver um jogo de futebol, devido a animação e empolgação da torcida e a experiência de ver algo diferente. Assim como no futebol masculino, adoraria ir acompanhada dos meus amigos" (E4). 
"Mesmo não gostando muito de futebol adoraria assistir um jogo com os meus amigos ou família, contanto que se criasse o mesmo clima ou expectativa para o jogo que nem se tem para os times de futebol masculino. Como minha família torce para o Fluminense e alguns dos meus melhores amigos também, iria no estádio para ver os para ver os jogos do time" (E2)

A participação do público em uma partida de futebol faz diferença, uma vez que deixa o jogo mais emocionante e o público sente uma conexão com os jogadores, podendo incentivá-los na busca da vitória. O surgimento e a consolidação do mercado consumidor de espetáculo são resultado de um processo de popularização, sendo assim pode se dizer que a popularização do jogo trouxe uma oportunidade para o surgimento do espetáculo no esporte (GIULIANOTTI,2002).

Entretanto, as interações entre clientes também afetam a experiência do serviço. Quando há o encontro com outros clientes em um ponto de serviços, a empresa precisa saber que eles podem afetar a satisfação um do outro. As implicações são claras: as comunicações de marketing precisam ter cuidado de atrair o segmento correto para o ponto de serviço, e, feito isso, devem educá-lo quanto ao comportamento adequado e conscientizá-lo a evitar comportamentos desagradáveis que possam prejudicar a experiência de serviço dos outros a seu redor (LOVELOCK; WIRTZ e HEMZO, 2012).

Neves (2005) acredita que a expectativa criada pelo consumidor é formada através da divulgação, entre clientes, de suas próprias necessidades, de serviços similares ou de prévias experiências com a empresa. O mesmo autor afirma que as empresas desenvolvem certa percepção sobre as preferências dos consumidores, levando tais percepções para as especificações de seus serviços. Nesse sentido, se entende que "é preciso pesquisar necessidades e desejos dos consumidores e buscar soluções inovadoras” (COBRA, 2001).

Além disso, a expectativa sobre um evento pode surgir durante o processo de busca e tomada de decisão sobre ir em um evento. Durante essa pesquisa as expectativas são profundamente modeladas pela busca de informações e avaliação de atributos. Se um cliente não tem experiência prévia relevante, pode basear suas expectativas em comentários de boca a boca, notícias ou nas próprias ações de marketing da empresa (LOVELOCK; WIRTZ e HEMZO, 2012). No futebol feminino, mesmo sem acompanhar com frequência o esporte, as pessoas já tem a sua própria expectativas sobre o esporte: 
"Eu gostaria de ver um investimento maior no esporte, onde a CBF fizesse ações de marketing sobre o esporte e aumentasse o investimento no futebol feminino. Gostaria que houvesse um aumento no investimento para os clubes e na seleção, ao invés de ser uma obrigação, já que atualmente para disputar a série $A$ do Brasileirão masculino os clubes precisam ter times femininos. Com esse investimento acredito que os times vão conseguir ter condições melhores de treinamento e os campeonatos ficarão mais competitivos e os jogos ficarão tão divertidos quanto o masculino" (E1).

"No futebol feminino eu gostaria de ver mais visibilidade, patrocínio e anúncios. Que outras jogadoras também ganhassem destaque além da Marta e que tivesse uma igualdade maior entre as jogadoras e os jogadores. Por fim, gostaria que tivesse horários

melhores ou mais acessíveis para os jogos e que até esses jogos fossem mais acessíveis a todos, através de promoções. Assim, mais pessoas poderão assistir os jogos" (E3).

"Atualmente percebo que tem uma grande diferença entre o futebol feminino e o masculino. Acredito que o futebol feminino é deixado em segundo plano e acaba não recebendo apoio nem investimento. Logo, algo que seria interessante ver o esporte recebendo uma maior verba para conseguir crescer, pois mesmo sem ela já temos grandes jogadoras como a Marta, a Cristiane e a Formiga" (E5).

"Eu gostaria de ver o esporte sendo reconhecido igual ao masculino, com as propagandas grandiosas, altos investimentos e salários, os momentos de glória e os estádios lotados. Gostaria que também tivesse uma torcida mista, que nem tem atualmente no futebol masculino" (E4).

Logo, podemos perceber que houve um despertar da necessidade, que surgiu a partir da percepção de desequilíbrio entre a situação real e a situação desejada do futebol feminino. Normalmente essa conscientização impulsiona a busca por informações e a avaliação das alternativas que reduzam ou eliminem esta sensação de desequilíbrio (LOVELOCK; WIRTZ e HEMZO, 2012).

Após tomar uma decisão de compra, os consumidores passam para a essência da experiência do serviço: a fase de encontro de serviço. Esse é um período durante o qual os clientes interagem diretamente com um serviço. É conhecido como 'hora da verdade', pois o que está em jogo é o relacionamento de longo prazo com os seus clientes (LOVELOCK; WIRTZ e HEMZO, 2012).

Dentre as características acima mencionadas sobre esse fator, podemos notar que os clientes ainda não vivenciaram tanto o evento presencialmente. 
Depois da copa do mundo feminina de 2019, algumas pessoas começaram a ver notícias sobre futebol feminino, mas nunca foram assistir o esporte presencialmente, ou seja, em um estádio de futebol. Porém, possuem esse desejo quando forem permitidos novamente público no estádio:

"Eu acompanho muito o futebol masculino, sempre que podia ia ao Maracanã acompanhar o Fluminense. Porém não tenho a mesma dedicação com o futebol feminino. Ultimamente tenho acompanhado mais, pois acho que a iniciativa precisa vir de mim. Planejo ir aos estádios quando permitirem" (E1).

"Adoraria ir ao estádio para ver algo diferente com os meus amigos. Gostaria que o público tivesse a mesma empolgação que tem no futebol masculino e que os estádios ficassem lotados da mesma forma" (E4).

"Gostaria de ir em um jogo com a minha família ou meus amigos, para ver algo diferente e apoiar as meninas, que normalmente não recebem o mesmo tipo de apoio. Mesmo não gostando muito de futebol, acho que seria legal fazer uma programação diferente com as pessoas que eu gosto" (E2).

Durante a fase de pós compra do consumo de serviços é onde acontece a comparação do desempenho às expectativas feitas antes do serviço ser contratado. Então, quando as expectativas são atendidas, os consumidores ficam satisfeitos. Entretanto, em mercados não competitivos ou em situações nas quais os consumidores não têm livre escolha, existem riscos em definir a satisfação do cliente em relação a suas expectativas prévias. Nestas situações, é melhor usar necessidades ou desejos como padrões de comparação e definir a satisfação em relação ao atendimento dessas necessidades ou desejos em vez das expectativas (LOVELOCK; WIRTZ e HEMZO, 2012).

De acordo com Kotler (2011), existem 10 exigências mais importantes para a prestação de serviços de alta qualidade: Funcionários experientes; Atendimento às minhas necessidades no primeiro contato; Trate-me como um cliente valioso; demonstre desejo de satisfazer minhas necessidades; possa acessar informações rapidamente; Boa relação custo-benefício; Funcionários amáveis; Seja uma empresa / marca na qual eu possa confiar; Trate-me de forma justa; Forneça serviço relevante / personalizado.

Como mostrado no Capítulo 2, para que um serviço apresente todos os elementos da qualidade e seja sentido como excepcional pelo cliente é preciso que os 5 gaps sejam eliminados. Os gaps significam as divergências que ocorrem 
dentro de uma empresa e entre a empresa e o cliente, o que resulta em má qualidade na prestação do serviço.

Os gaps são considerados como falhas no planejamento organizacional, ocorrendo quando este não atinge o resultado esperado. Caso essas falhas sejam percebidas pelos clientes, elas poderão influenciar negativamente sobre o serviço experimentado, o que é tecnicamente chamado de "custo de falha externa da qualidade" (KOTLER,2011).

De acordo com Kotler (2011), para que um serviço apresente todos os elementos da qualidade e seja percebido como excepcional pelo cliente é preciso que os cinco gaps sejam eliminados. Esta discrepância entre o serviço percebido e o serviço esperado faz com que o cliente avalie o serviço da empresa como "sem qualidade".

Considerando o acima exposto, quando questionados sobre a qualidade do futebol feminino, as respostas foram bem parecidas às respondidas sobre a visão que eles tinham sobre o esporte:

"Infelizmente mesmo acompanhando mais o futebol feminino nesses últimos anos, ainda tenho a visão que ele pode melhorar muito. A falta de investimento e o machismo ainda atrapalham o crescimento do esporte" (E1).

"Acredito que o futebol feminino tem um grande potencial de crescimento. Ainda é difícil para o pessoal da minha idade começar a acompanhar o futebol feminino, pois crescemos com a ideia de que o único futebol que é bom é o masculino. Entretanto podemos ver que isso não é verdade, já que mesmo com todas as dificuldades estamos vendo grandes jogadoras como Marta, Formiga e Cristiane brilharem no esporte" (E5).

"Mesmo não acompanhando muito futebol, ainda sinto que o evento não tem a sua devida valorização, uma vez que ainda é visto como inferior ao futebol masculino. $O$ machismo e a falta de investimentos são dois pontos que atrapalham bastante 0 crescimento do esporte" (E2),

Sendo assim, podemos perceber que vários gaps's de serviços precisam ser trabalhados para que o futebol feminino consiga crescer e se estabilizar. Mesmo que a visão do esporte tenha melhorado bastante nos últimos anos, ainda se precisa trabalhar bastante no GAP 5 que é quando tem uma contraposição entre o que o cliente espera e a percepção que ele tem do serviço oferecido, devido a grande comparação com o futebol masculino. 


\subsection{Empresas no esporte}

Hoje é crescente o número de empresas que, atuando como patrocinadores do esporte, da cultura, do social e da ecologia, utilizam as ações de patrocínio como fator de alavancagem das suas ações estratégicas de marketing. Na condição de ação promocional de caráter estratégico, o patrocínio atua como elo entre o mix de marketing da empresa e o seu composto promocional. Daí sua importância crescente e a sua rápida disseminação em todo o mundo, por empresas de diferentes tamanhos e atuantes em diversos setores da sociedade.

O esporte trabalha na construção das marcas esportivas à medida que fornece uma emoção que as mobiliza e valoriza, gerando prestígio e agregando valor. Presente nos uniformes de equipes, a marca é capaz de tornar seus atributos visíveis ao consumidor, possibilitando que ele veja a marca correr, jogar, vencer e disputar.

A força de uma marca, incluindo as marcas esportivas, é construída segundo Kotler (2000) de maneira holística, por meio de orquestrações de um conjunto de ferramentas, inclusive propaganda, relações públicas, patrocínios, eventos, causas sociais e porta-vozes. Para as marcas esportivas o patrocínio apresenta importância singular nesse processo.

Segundo Mello Neto (2000), o patrocínio esportivo descreve claramente o novo momento do marketing, onde ele deixa de ser somente o marketing de produtos e atributos para valorizar o marketing da empresa, de atitudes e de experiências. Oliveira e Pozzi (1996) ressaltam essa capacidade do patrocínio ao afirmar que o maior benefício que o patrocínio esportivo oferece é transferir a emoção e a competitividade do esporte para a marca do patrocinador. Os autores concluem que o patrocínio é ainda capaz de reforçar a imagem corporativa e estabelecer identificação com segmentos específicos do mercado.

Entretanto, quando perguntados sobre quais as marcas que eles associavam ao futebol feminino, muitos tiveram dificuldades em lembrar de alguma ou listaram poucas marcas:

"Pensando rapidamente, consigo lembrar da Avon pois ela é a patrocinadora da Marta. Também consigo lembrar da Clear e Nike que já fizeram algumas propagandas sobre futebol feminino. Mas sinto que essas propagandas são isoladas e de forma insuficiente. No futebol masculino sempre vemos grandes patrocínios e propagandas como a Budweiser com a Champions League, mas isso não acontece com o futebol 
"Atualmente ainda é muito difícil ver propagandas sobre o futebol feminino, mesmo que eles tenham aumentado durante e depois da Copa do Mundo de 2019. Por enquanto só consigo lembrar da Nike e do Guaraná Antártica, que fizeram propaganda da seleção feminina. Uma atitude que me marcou bastante que justamente aconteceu durante a Copa do Mundo de 2019 foi em relação à Marta. Em um dos jogos da seleção ela marcou um gol importante e em seguida apontou para a chuteira, indicando que não tinha patrocinador. É triste ver que a jogadora mais famosa da nossa seleção não tinha um patrocinador oficial" (E4).

"Eu já vi algumas poucas marcas que patrocinam o futebol feminino, mas devo admitir que para conseguir lembrar de algumas delas precisei pesquisar na internet. Acho que a propaganda que mais me marcou foi a do Guaraná Antártica, pois foi uma das primeiras marcas que patrocinou a seleção feminina" (E2).

Segundo Keller e Machado (2006), há uma série de razões para o patrocínio de eventos: identificar um público-alvo ou estilo de vida específico; majorar a lembrança da marca; criar ou reforçar as percepções do consumidor das associações-chaves de imagem da marca; promover dimensões da imagem da empresa, criar experiências e provocar sentimentos; demonstrar comprometimento com a sociedade e com causas sociais e, ainda, entreter clientes importantes ou recompensar seus colaboradores (áreas especiais em eventos). Para Melo Neto (2007), o patrocínio caracteriza-se por ser uma mídia alternativa e a visibilidade proporcionada pelo esporte permite às organizações terem poder de penetração imenso em milhares de espectadores, telespectadores, leitores e praticantes em todo o mundo (HAIACHI; MATARUNA, 2008).

A fim de criar consciência perante os consumidores, as marcas utilizam as diferentes mídias, caracterizadas por Sant'Anna (1989) como os veículos escolhidos pelas empresas para divulgar suas mensagens. Para Kotler (2000), o anunciante ao escolher um tipo de mídia deverá atingir certo alcance, frequência, impacto e continuidade tendo em vista o mercado-alvo que pretende atingir.

Existe uma atividade de comunicação centrada na utilização do esporte como mídia alternativa e voltada para alcançar certo público. O patrocínio é parte de um composto promocional da empresa e para tanto deve estar integrado em seus objetivos promocionais e institucionais.

É um novo segmento de mercado de comunicação, uma mídia alternativa, e trata-se de um tipo de marketing promocional que atua na dimensão institucional 
de empresa visando à maximização da exposição de uma marca (MELO NETO, 1995).

Ao analisarmos as respostas desse grupo, podemos perceber que as propagandas voltadas para o futebol feminino ainda são em quantidades insuficientes. Durante a Copa do Mundo Feminina de 2019, muitas empresas fizeram campanhas sobre o evento, e isso foi lembrado pela maioria dos entrevistados. Entretanto, após o evento a quantidade de propagandas voltou para o que era antes da Copa, algo que ainda chama a atenção dos entrevistados:

"Realmente não costumo ver quase nenhuma propaganda sobre os eventos esportivos ou das suas marcas patrocinadoras. Lembro que algumas empresas como a

Nike e Guaraná Antártica fizeram campanhas sobre a seleção feminina alguns anos atrás. Entretanto, não me lembro de nenhuma marca que patrocina algum campeonato ou jogadora" (E5).

"Atualmente não vejo nenhuma propaganda ou anúncio sobre os campeonatos femininos de futebol. A única que eu lembro de ter visto foi sobre a Copa do Mundo Feminina de 2019. Gostaria que tivesse mais patrocínio em relação aos campeonatos e jogadoras, acho que ajudaria não só no crescimento do esporte feminino, mas as marcas também ficariam com uma imagem muito positiva." (E3).

"Normalmente não vejo anúncio de nenhuma marca específica sobre um campeonato de futebol. Normalmente só escuto alguma notícia de futebol feminino quando tem algum jogo importante, ou seja, dias pontuais. Assim, não consigo associar muitas marcas ao futebol feminino" (E2).

É possível concluir que as falas acima mencionadas não concordam com as teorias abordadas, pois, as marcas estão perdendo uma grande oportunidade de se destacarem e serem pioneiras em patrocinar as atletas e campeonatos de futebol feminino. Além disso, é possível perceber que esse grupo nota quais marcas estão patrocinando o esporte. Sendo assim, o patrocínio de eventos e atletas ligados ao futebol feminino pode ser uma grande oportunidade para grandes marcas se destacarem e se conectarem com o público mais jovem.

Para Mishra et al. (2001), entre os principais fatores considerados pelas organizações na seleção de um endossante estão a credibilidade e a simpatia da personalidade, pois tem sido relatado ser menos eficaz uma celebridade que endossa mais de um produto. Ohanian (1990) agrega, ainda, o conceito de atratividade do endossante como uma dimensão a ser considerada na escolha de 
uma personalidade. Para este autor, as mais atraentes são também consideradas as mais benquistas, e têm um impacto positivo na avaliação dos produtos. Keller e Machado (2006) corroboram a posição de Mishra et al. (2001), quando declaram que o uso de uma celebridade no endosso de vários produtos pode resultar em falta de qualquer significado específico de produto. Ao mesmo tempo, pode haver reflexo em sua reputação, sendo elas consideradas oportunistas. Keller e Machado (2006) relatam, ainda, que os consumidores, muitas vezes, creem que o endossante não acredita na marca representada ou nem mesmo a usa.

Podemos perceber que desde o início das entrevistas sempre teve uma atleta que se destacou: a jogadora Marta. Todos os entrevistados a citaram como uma excelente jogadora e exemplo de superação, pois mesmo com todos os problemas já mencionados ela não desistiu e se tornou a jogadora mais importante da seleção brasileira.

"A Marta me ajudou a começar a acompanhar o futebol feminino. Ainda fico triste vendo uma jogadora do nível dela, que é a artilheira em copas do mundo e da seleção brasileira, e que já foi eleita mais de 5 vezes a melhor jogadora do mundo até pouco tempo atrás não ter um patrocinador. Ela ainda recebe um salário muito menor de outros atletas masculinos que não alcançaram os mesmos números que ela. Isso realmente desmotiva muitas mulheres a continuarem no esporte." (E1).

"A Marta é um exemplo de superação. Se com pouco investimento ela já fez e ainda faz história pelo futebol feminino, imagina o que ela faria com o mesmo investimento de times e atletas masculinos. Acredito que se as jogadoras começarem a ter o mesmo investimento, o esporte feminino irá crescer rapidamente" (E5).

Mullin, Hardy e Sutton (2004) afirmam que o modelo tradicional não se apresenta como ideal devido ao ruído presente nas mídias e o fato de custos de propaganda, especialmente na televisão, continuarem a subir desenfreadamente. No Brasil é um modelo que ainda se mostra dominante, mas que com o crescente poder do consumidor pode estar tendendo ao declínio.

A tendência é descrita por Donaton (2004), ao citar que o modelo tradicional de propaganda está gasto por se tratar de um modelo invasivo que não consegue mais atrair a atenção do consumidor à medida que seu foco é em presença, e não impacto. Segundo o autor, é preciso um novo modelo, com foco em envolvimento e baseado na integração da mensagem comercial ao conteúdo. $O$ entretenimento surge como grande oportunidade, tendo em vista que the integrando mensagens o anunciante é capaz de atingir os consumidores em um 
momento em que eles tendem a estar mais receptivos e abertos. Ao utilizar o entretenimento como plataforma de comunicação, o mercado consegue atingir o coração das pessoas e suas mentes, nessa ordem, pois, como frisa Danton (2004 p. 30), "este é o caminho para suas carteiras".

Marcas como Nike, Adidas e Reebok, ao se encaixarem no conteúdo esportivo ganham credibilidade à medida que se tornam parte de algo com que as pessoas escolhem gastar seu tempo, e como apontado por Oliveira e Pozzi (1996) conseguem que durante a transmissão de um evento esportivo suas mensagens cheguem a um telespectador cativo, em um momento de relaxamento e sob uma forma não-imperativa de venda.

Conforme já mencionado, o reforço da imagem corporativa apontado por Oliveira e Pozzi é descrito por Vaz (1995) como a prática do marketing institucional. "O termo institucional é usado para indicar as iniciativas através do qual uma empresa procura fixar junto ao público uma imagem positiva da organização. Para tanto, busca associar o seu nome a determinados valores e conceitos consagrados pela opinião pública" (Vaz, 1995, p. 7). A dimensão institucional compreende, portanto, a imagem da empresa diante da opinião pública, a força do seu nome e sua marca e os atributos e conceitos ligados a seus produtos. Como podemos concluir, isso não está acontecendo em relação ao futebol feminino:

"Consegui pensar na empresa em que trabalho, por causa da Copa do Mundo.

Como o evento aconteceu na França e a empresa surgiu lá, eles fizeram algumas propagandas sobre a Copa e liberaram os funcionários nos dias de jogos. Além disso, lembrei da Nike, mas não tenho certeza se a empresa é um patrocinador forte do futebol feminino. Mas tirando essas empresas não penso em mais nenhuma." (E4).

"Eu lembrei até de bastante empresas como Nike, Itaú, Vivo, Adidas e Guaraná Antártica. Porém só lembro delas terem feito propagandas durante a Copa do Mundo. Depois tiveram poucas propagandas dessas empresas e outras também decidiram não as patrocinar" (E5).

Dessa forma, em consonância com o apresentado acima é possível concluir que não é preciso de muito esforço das empresas para chamarem a atenção dos consumidores para as suas empresas. É somente necessário que as empresas adotem uma boa estratégia de marketing voltada para o futebol feminino, algo que já é solicitado pelo público. Os resultados encontrados estão 
de acordo com a teoria acima, pois ela defende que é necessário ter um bom mix de marketing para resultar na melhora da imagem da marca em relação ao público-alvo. 


\section{Conclusões e recomendações para novos estudos}

Este trabalho teve como objetivo contribuir para investigar a relação das ações de marketing com a visibilidade do futebol feminino na sociedade e principalmente para os fãs do esporte, bem como verificar se a faixa etária interfere na percepção que as pessoas tem em relação ao futebol feminino. Outro tema muito presente durante o estudo foi o marketing de eventos. Por meio deles também procurou-se identificar como o esporte está sendo divulgado, como as pessoas estão interagindo com o evento esportivo, a percepção dessas pessoas sobre esse esporte e como as marcas estão contribuindo para a divulgação do futebol feminino. A partir desse estudo sobre marketing de eventos também foi identificado quais são as maiores barreiras e dificuldades de crescimento do esporte.

Os estudos sobre esses assuntos são importantes pois eles sempre são focados no futebol masculino, mesmo com o recente aumento de visibilidade e popularidade da modalidade feminina. Com o passar dos anos e na medida em que o acesso à informação se tornou mais amplo, percebeu-se que o consumidor se utiliza cada vez mais de diversas informações e fontes de dados para tomar decisões de compra, estabelecendo certa hierarquia de valores, desejos e necessidades baseado em dados empíricos, propaganda de boca-a-boca, opiniões diversas e experiências anteriores com serviços e produtos (McKENNA, 1992). Por mais que as organizações tentem, a exigência pela igualdade e inovação no futebol tem se tornado cada vez mais comum. Por esse motivo, o intuito deste estudo foi de auxiliar uma forma das empresas utilizarem uma estratégia de marketing para essa demanda.

Para atingir os objetivos deste estudo, foram realizadas cinco entrevistas qualitativas com pessoas que gostam e outros que nem são tão fãs de futebol. Dentre os selecionados havia pessoas que torciam para os grandes clubes do Rio de Janeiro, Vasco, Flamengo e Fluminense. Além disso, também foram selecionadas pessoas que já estão inseridas no mercado de trabalho e outras que ainda vão entrar. Por fim, para que a amostragem fosse a mais diversificada possível, também foram considerados jovens brasileiros, graduandos, recémformados e formados de todos os cursos.

Durante as entrevistas foi possível perceber que muitas das características presentes nas literaturas, a respeito dos eventos esportivos que se comprovam. 
Além disso, outros aspectos em relação a visibilidade do esporte, consideradas importantes para o crescimento do futebol feminino, também foram confirmados.

Em relação à visão que os jovens tem em relação ao futebol feminino, é possível perceber que mesmo os que gostam de futebol tem dificuldade de acompanhar o futebol feminino. Mesmo tendo acesso a mais locais de notícias, ainda é difícil de se acompanhar a modalidade. De acordo com Lovelock; Wirtz e Hemzo (2011), os clientes precisam ser educados sobre a melhor forma de usar um serviço, pois se o cliente souber usar bem um serviço além de ter uma melhor experiência e resultado ele também terá uma maior eficiência que poderá impulsionar a produtividade da empresa e reduzir os custos.

Nessa faixa etária também é possível perceber uma grande demanda por igualdade dentro do futebol, onde todos recebam os mesmos salários e premiações e recebam o mesmo investimento. Há também a demanda por reconhecimento, onde os jogadores são tratados da mesma forma.

Outro aspecto importante a ser comentado é em relação à crescente busca pelo futebol feminino. Mesmo com a dificuldade de se encontrar notícias sobre a modalidade, quem segue os perfis oficiais dos seus respectivos times nas redes sociais consegue ter uma ideia de qual jogo teve e o seu respectivo placar.

Independentemente da natureza do evento, o sucesso depende largamente da promoção, pois é vital para criar conscientização do evento, desejo por participação e sentimento por parte do participante potencial de que o investimento em tempo e dinheiro vale os benefícios oferecidos (HOYLE JR.,2003 p.49). Mesmo com a pouca divulgação e todas as dificuldades, a grande maioria se mostrou interessada em assistir e ir em um jogo de futebol feminino, principalmente quando envolve um grande jogo, família e amigos.

Além disso, foi analisado que os jovens querem ver outras estrelas no futebol feminino além da Marta. Todos citaram ela como um grande exemplo de superação, entretanto sabem que infelizmente ela não vai poder jogar futebol por muito mais tempo. E para que isso aconteça, é necessário ter um maior investimento no setor.

Em relação às estratégias de divulgação das empresas sobre o esporte, foi identificado que a maioria das marcas só começaram a fazer propagandas sobre o futebol feminino nos últimos dois anos, desde a Copa Feminina de 2019. Entretanto, elas ainda são insuficientes, pois muitas pessoas não se lembram da divulgação de times ou jogadoras. 
Para Ferrand e Pages (1999), a imagem de uma organização esportiva pode agregar valor para si próprio. A imagem contribui para o reforço da marca (Brand Equity) e também favorece mudanças no comportamento do consumidor. Normalmente a imagem de uma organização esportiva deriva da conotação dada ao esporte em questão, personalidades existentes em seu meio e os títulos conquistados pela entidade. Logo, podemos concluir que ainda há bastante espaço para as marcas crescerem dentro da modalidade.

Sendo assim, considerando os objetivos principais do presente estudo é possível concluir que o futebol feminino tem bastante espaço para crescimento e desenvolvimento, uma vez que há um público interessado em assistir e acompanhar o futebol feminino. Já em relação às marcas no futebol feminino, foi possível perceber que há espaço para novos investimentos e para as marcas se destacarem no esporte.

Por fim, para futuros trabalhos, é indicado abordar os temas da visibilidade do futebol feminino nas gerações mais antigas e nas próximas gerações. Dessa forma, será possível definir o melhor público-alvo inicial para a modalidade e quais são as melhores estratégias de marketing que podem ser utilizadas. Além de ser um estudo muito importante para os times e possíveis investidores, pois assim irão saber com quem devem se comunicar. 


\section{Referências Bibliográficas}

ALIANO, Dutra Felipe; BIAVA, Luísa. Marketing Esportivo no Futebol: Um Estudo das Estratégias dos Clubes da Primeira Divisão do Futebol Brasileiro no ano de 2012, Santa Catarina 2013. Dissertação (Graduação em Administração) Departamento de Administração: Universidade Federal de Santa Catarina.

ASSIS, Evange Elias; TOLEDO, Luciano; PISCOPO, Marcos Roberto; ROSA, Claudionor de Moraes As Mídias Sociais Sob A Perspectiva Do Marketing Esportivo: O Caso São Paulo Futebol Clube, Revista do Programa de Estudos Pós-Graduados em Administração: Pensamento \& Realidade. v. 29, n. 1 (2014)

BALARDIN, Georgia Fernandes Espaço midiático do futebol feminino no rio grande do sul : um estudo a partir do regulamento da Conmebol Porto Alegre, 201827 p. Tese de Conclusão de Curso (Graduação em Educação Física) Departamento de Educação Física, Fisioterapia e Dança: Universidade Federal do Rio Grande do Sul

BORGES, Claudio N. Emoção, Exposição E Vendas Análise Do Patrocínio Realizado Por Marcas de Artigos Esportivos no Futebol Brasileiro. Rio de Janeiro, 2008. 13 e 14 p. Tese de Conclusão de Curso (Graduação em Administração), Departamento de Administração: Pontifícia Universidade Católica do Rio de Janeiro.

CAMPOS, Sergio Furtado. Um Estudo Sobre a Importância Das Características Dos Projetos De Patrocínio Na Visão Das Empresas Patrocinadoras De Eventos Rio de Janeiro, 2008 Dissertação (Mestrado em Administração), Departamento de Administração: Pontifícia Universidade Católica do Rio de Janeiro

CHAVES, Alex, S. O futebol feminino: uma história de luta pelo reconhecimento social. Revista digital Buenos Aires, v. 12 n. 111 p.34 (2007)

CHAVES, Gonçalves Paula; GOSLING, Marlusa; Alves, De M. Sandro. Engajamento e Ações De Marketing De Relacionamento No Futebol, Revista das Faculdades Integradas Vianna Júnior, V.5 n.1 p. 32 (2017) .

FERREIRA, C. Renan, Marketing Esportivo No Futebol Brasileiro: Análise De Relacionamento Dos Times Com Torcedores De Cidades Distantes Daquelas Em Que Estão Instalados, Paraná, 2016 Tese de Conclusão de Curso (especialização) Setor de Ciências Sociais Aplicadas, Curso de Especialização MBA em Marketing Universidade Federal do Paraná (UFPR)

FRANÇA, do V.Israilda; PORTELA, L. Girlene, A Imagem do Esporte na Propaganda: uma Análise Discursiva Anais Seminário de Iniciação Científica; Feira de Santana - Portal de Periódicos Eletrônicos da Universidade Estadual de Feira de Santana (UEFS), 2017 
GASS, Natascha O Jogo das Marcas: A Repercussão Espontânea das Marcas nas Mídias Através da sua Presença no Estádio na Final do Gauchão 2014, Porto Alegre 2014, Tese de Conclusão de Curso (Graduação em Comunicação Social- Publicidade e Propaganda), Departamento de Comunicação: Universidade Federal do Rio Grande do Sul (UFRGS).

GONÇALVES, André Seabra Viabilidade das Experiências do Sport Lisboa e Benfica no B2C Lisboa 2012, 129 p., Dissertação (Mestrado em Marketing) Instituto Superior de Ciências do Trabalho e da Empresa: Instituto Universitário de Lisboa

GUARAGNA, Frederico Mandelli A Gestão do Marketing Esportivo no Futebol: Caso Grêmio Foot-Ball Porto Alegrense Porto Alegre 2005, 100p. Dissertação (Graduação em Administração) Departamento de Administração: Universidade Federal do Rio Grande do Sul (UFRGS)

HOYLE JR. Leonard H. Marketing de Eventos. Como promover com Sucesso Eventos, Festivais, Convenções e Exposições. São Paulo: Editora Atlas. 1 ed. 2003,

KELLERMANN, Bruna, S. O Futebol Feminino em Expansão: Determinantes, Políticas Públicas e Perspectivas. Subsídios Para a Compreensão do Contexto Brasileiro.Évora 2020, 132 p. Dissertação (Mestrado em Direção e Gestão Esportiva) Universidade de Évora - Escola de Ciências e Tecnologia.

KESSLER, Claudia Samuel Mais que Barbies e Ogras : Uma Etnografia do Futebol de Mulheres no Brasil e nos Estados Unidos, Rio Grande do Sul, 2015,Dissertação (Pós- Graduação em Antropologia Social) Departamento de Filosofia e Ciências Humanas Universidade Federal do Rio Grande do Sul (UFRGS).

KROPMANNS, Da S. Ramon, O Marketing Esportivo No Futebol Brasileiro A Força De Uma Marca - Estudo De Caso Da Era Palmeiras Parmalat, Paraná 2017, Dissertação (Graduação em Publicidade e Propaganda) Departamento de Comunicação Social Universidade Federal Do Paraná

LOVELOCK, Christopher; WIRTZ, Jochen; HEMZO, Miguel Angelo Marketing de Serviços Pessoas, Tecnologia e Estratégia São Paulo Editora: PEARSON $7^{\circ}$ edição 2011.

MARTÍNEZ, Mina; YANETH Claudia; GOELLNER, Silvana; OROZCO, Rodríguez, AURA, María Soccer and Women: The Panorama of The Professional Women's Soccer League in Colombia, Educación Física y Deporte; vol. 38 n.1 p. 40 (2019)

NUNES, Joana Sofia dos Santos Patrocínio: Influência na Atitude Relativamente à Marca e Intenção De Compra: Caso Nike e Selecção Portuguesa de Futebol Portugal 2014, Dissertação (Graduação em Comunicação Social) Departamento de Comunicação Social Escola Superior de Comunicação Social. 
PROCHNIK, Luisa Práticas e Estratégias Narrativas no Jornalismo Esportivo uma Análise de Notícias Sobre a Seleção Brasileira na Copa do Mundo 2010 em Sites Jornalísticos Rio de Janeiro 2011, Dissertação (Mestrado em Comunicação Social) Departamento de Comunicação Social Pontifícia Universidade Católica do Rio de Janeiro

Rocco de Oliveira, Luciana Mazzei, Leandro Carlos Rocco Júnior, Ary José Soares César, Fábio Perspectivas de Ações de Marketing Esportivo nos Eventos Escolares: Um Estudo Sobre Marcas e Patrocínio. Revista Intercontinental de Gestão Desportiva v. 3 n. 1 p.70 (2013)

SALVINI, Leila; MARCHI JÚNIOR, Wanderley Notoriedade Mundial e Visibilidade Local: O Futebol Feminino na Revista Placar na Década De 1990 Sociologias Plurais: Biblioteca Digital de Periódicos da UFPR, v. 1, n. 1 p.50 (2013)

SEVERO DE ALMEIDA, Marcos Inácio; FRANÇA COELHO, Ricardo Limongi; SANTOS DE OLIVEIRA, Denise; CAMARGO, Altair; SAVIOLI, Pedro Sales-based Brand Equity as a Performance Driver in 'The Country of Soccer RAC - Revista de Administração Contemporânea v. 24 n. 2 p 134-150, 2020.

VILELA, Soffia Raquel Ferreira; MARQUES, leso Costa Marketing De Relacionamento Em Serviços Odontológicos Goiás 2018, Centro Universitário de Anápolis - UniEVANGÉLICA

BBC Brasil Londres 2012: A evolução da participação feminina nos Jogos. Brasília 2012. Disponível em: <https://www.bbc.com/portuguese/noticias/2012/07/120720 olympics modulo m ulheres olimpiadas rw.shtml> Acesso 01 de junho de 2020

Blog de marketing digital. Copa do Mundo e Recorde da Marta. Rio de Janeiro 2019. Disponível em: <https://resultadosdigitais.com.br/blog/marketing-futebolfeminino/> Acesso 07 de abril de 2020

Globo Esporte .Público Recorde em jogos de futebol feminino no Brasil. São Paulo 2019. Disponível em: <https://globoesporte.globo.com/futebol/times/corinthians/noticia/torcida-docorinthians-estabelece-novo-recorde-de-publico-num-jogo-de-futebol-femininono-brasil.ghtml> Acesso em 15 de abril de 2020

Globo Esporte. História do Futebol Feminino. Rio de Janeiro <https://globoesporte.globo.com/outros-esportes/noticia/mulheres-no-esporte-otabu-e-a-historia-por-tras-da-pouca-representatividade-feminina.ghtml> Acesso em 06 de abril de 2020

$\mathrm{M}$ de mulher. Você sabia que o futebol era proibido para mulheres no Brasil até 1979? São Paulo, 2019. Disponível em: $<$ https://mdemulher.abril.com.br/estilo-de-vida/voce-sabia-que-o-futebol-eraproibido-para-mulheres-no-brasil-ate-1979/> Acesso em: 01 de junho de 2020 
Metrópolis. Mulheres da seleção americana ganham seis vezes menos que os homens. São Paulo, 2019 Disponível em: $<$ https://www.metropoles.com/esportes/futebol/mulheres-da-selecao-americanaganham-seis-vezes-menos-que-os-homens> Acesso em 01 de junho de 2020 Nexo. No país do futebol, as mulheres jogam com menos. São Paulo 2018. Disponível em: <https://www.nexojornal.com.br/reportagem/2017/05/28/Nopa\%C3\%ADs-do-futebol-as-mulheres-jogam-com-menos-falta-sal\%C3\%A1riop\%C3\%BAblico-e-estrutura> Acesso em 06 de abril de 2020

Rede Brasil Atual. Futebol feminino resiste, sem patrocínio. 2018. Disponível em: <https://www.redebrasilatual.com.br/esportes/2018/05/invisivel-e-sempatrocinio-futebol-feminino-brasileiro-resiste/> Acesso 06 de abril de 2020

Revista Marie Claire Como o feminismo tem mudado o futebol feminino.Junho de 2019.2 Disponível em: $<$ https://revistamarieclaire.globo.com/Comportamento/noticia/2019/06/copa-domundo-feminina-como-o-feminismo-tem-mudado-o-futebol-dasmulheres. html? GLBID=1c3b9bd247dcb31deac480d9d9acf5bb05f41444116b466c 5163513834485871575942696347696f7534694a41744e6e766c3055786d564b7 057676441365f6b322d37344662514d374a7a43332426c454d45446663507333368 45526a4f7a75376464576d6164413d3d3a303a6172617a7664732e32303136 > Acesso em 17 de abril de 2020

Secad.Participação de mulheres no esporte cresce, mas ainda é inferior a dos homens. São Paulo outubro de 2018. Disponível em: $<$ <https://www.secad.com.br/blog/fisioterapia/mulheres-no-esporte-participacao/> Acesso em 01 de junho de 2020 UOL. Desvalorização do futebol feminino. São Paulo 2019. Disponível em: $<$ https://maquinadoesporte.uol.com.br/artigo/futebol-feminino-tem-us-1-bi-desubvalorizacao 37550.html> Acesso em: 06 de abril de 2020 UOL. Descaso em o futebol feminino no Brasil. Rio de Janeiro 2019. Disponivel em: <https://dibradoras.blogosfera.uol.com.br/2019/07/16/estudo-da-fifa-mostradescaso-de-anos-do-brasil-com-o-futebol-feminino/> Acesso em 07 de abril de 2020

UOL. Récorde de público na Copa do Mundo feminina. Rio de Janeiro 2019. Disponível em: <https://dibradoras.blogosfera.uol.com.br/2019/10/18/copa-domundo-feminina-bate-recorde-e-supera-1-bilhao-de-espectadores/> Acesso em: 06 de abril de 2020 


\section{Anexo 1}

Pesquisa- Visibilidade do Futebol Feminino entre os jovens

- Nome:

- Idade:

- Estuda (Caso positivo, qual curso e faculdade):

- Trabalha:

1) A tabela abaixo do IBGE, indica o rendimento familiar mensal de cada uma das sete faixas estipuladas. A primeira coluna representa os intervalos de valores em reais e a segunda a quantidade de salários-mínimos. Sendo assim, de acordo com as informações acima e o seu rendimento mensal, em qual dessas faixas você se consideraria?

\begin{tabular}{lcc}
\hline Classe & Salários Mínimos (SM) & Renda Familiar (RS) \\
\hline A & Acima de $20 \mathrm{SM}$ & $\mathrm{R} \$ 18.740,01$ ou mais \\
$\mathrm{B}$ & 10 a $20 \mathrm{SM}$ & $\mathrm{R} \$ 9.370,01$ a R $\$ 18.740,00$ \\
$\mathrm{C}$ & 4 a $10 \mathrm{SM}$ & $\mathrm{R} \$ 3.748,01$ a R $9.370,00$ \\
$\mathrm{D}$ & 2 a $4 \mathrm{SM}$ & $\mathrm{R} \$ 1874,01$ a R $\$ 3.748,00$ \\
$\mathrm{E}$ & Até $2 \mathrm{SM}$ & Até RS $1.874,00$ \\
\hline
\end{tabular}

Fonte: IBGE (2018)

2) O que você conhece sobre futebol feminino?

3) Você acompanha futebol feminino? Por quê?

4) Qual a sua visão do futebol feminino?

5) O que você gostaria de ver no futebol feminino?

6) O que faria você ir assistir um jogo de futebol feminino?

7) O que faria você a ir a um jogo de futebol feminino?

8) Você vê notícias sobre o futebol feminino?

9) Você vê anúncios/ propagandas sobre os jogos/ campeonatos de futebol feminino?

10) Quais as marcas/ empresas vocês associam ao futebol feminino? 